FEDERAL RESERVE BANK OF SAN FRANCISCO

WORKING PAPER SERIES

\title{
Macrofinancial History and the New Business Cycle Facts
}

\author{
Oscar Jorda \\ Federal Reserve Bank of San Francisco \\ University of California, Davis \\ Moritz Schularick \\ University of Bonn and CEPR \\ Alan M. Taylor \\ University of California, Davis, NBER and CEPR
}

September 2016

Working Paper 2016-23

http://www.frbsf.org/economic-research/publications/working-papers/wp2016-23.pdf

\section{Suggested citation:}

Jorda, Oscar, Moritz Schularick, Alan M. Taylor. 2016. "Macrofinancial History and the New Business Cycle Facts” Federal Reserve Bank of San Francisco Working Paper 2016-23. http://www.frbsf.org/economic-research/publications/working-papers/wp2016-23.pdf

The views in this paper are solely the responsibility of the authors and should not be interpreted as reflecting the views of the Federal Reserve Bank of San Francisco or the Board of Governors of the Federal Reserve System. 


\title{
Macrofinancial History
} and the New Business Cycle Facts*

\author{
Òscar Jordà $^{\dagger} \quad$ Moritz Schularick Alan M. Taylor $^{\S}$
}

Paper presented at the NBER Macroeconomics Annual Conference 2016

\begin{abstract}
In advanced economies, a century-long near-stable ratio of credit to GDP gave way to rapid financialization and surging leverage in the last forty years. This "financial hockey stick" coincides with shifts in foundational macroeconomic relationships beyond the widely-noted return of macroeconomic fragility and crisis risk. Leverage is correlated with central business cycle moments, which we can document thanks to a decade-long international and historical data collection effort. More financialized economies exhibit somewhat less real volatility, but also lower growth, more tail risk, as well as tighter real-real and real-financial correlations. International real and financial cycles also cohere more strongly. The new stylized facts that we discover should prove fertile ground for the development of a new generation of macroeconomic models with a prominent role for financial factors.
\end{abstract}

JEL classification codes: Eo1, E13, E30, E32, E44, E51, F42, F44, G12.

Keywords: financial hockey stick, leverage, credit, moments, macroeconomics.

${ }^{*}$ We are grateful to Martin Eichenbaum and Jonathan Parker for their guidance and support. For helpful comments we thank our discussants Mark Gertler and Atif Mian, as well as the other conference participants. The scale of the data collection effort would not have been possible without the generous support of many colleagues at research institutions, national archives, central banks, and statistical offices who shared their data or directed us to potential sources. We are equally indebted to a large number of dedicated and enthusiastic research assistants in various places who chased references through many libraries and archives in various countries, in particular Katharina Knoll and Felix Ward. We are also especially grateful to Helen Irvin for outstanding assistance with the data analysis. Last, but not least, we have benefited from generous grants from the Institute for New Economic Thinking and the Volkswagen Foundation, who supported different parts of the data collection and analysis effort. The views expressed in this paper are the sole responsibility of the authors and do not necessarily reflect the views of the Federal Reserve Bank of San Francisco or the Federal Reserve System.

${ }^{\dagger}$ Federal Reserve Bank of San Francisco; and Department of Economics, University of California, Davis (oscar.jorda@sf.frb.org; ojorda@ucdavis.edu).

ҒDepartment of Economics, University of Bonn; and CEPR (moritz.schularick@uni-bonn.de).

$\S$ Department of Economics and Graduate School of Management, University of California, Davis; NBER; and CEPR (amtaylor@ucdavis.edu). 
When you combine ignorance and leverage, you get some pretty interesting results.

- Warren Buffett

\section{Introduction}

Observation is the first step of the scientific method. This paper lays empirical groundwork for macroeconomic models that take finance seriously. The Global Financial Crisis reminded us that financial factors play an important role in shaping the business cycle, and there is growing agreement that new and more realistic models of real-financial interactions are needed. Crafting such models has become one of the top challenges for macroeconomic research. Policymakers in particular seek a better understanding of the interaction between monetary, macro-prudential, and fiscal policies.

Our previous research (Schularick and Taylor 2012; Jordà, Schularick, and Taylor 2011, 2013, 2016ab) uncovered a key stylized fact of modern macroeconomic history that we may call the "financial hockey stick." The ratio of aggregate private credit to income in advanced economies has surged to unprecedented levels over the second half of the 2oth century. A central aim of this paper is to show that, alongside this great leveraging, key business cycle moments have become increasingly correlated with financial variables. Most importantly, our long-run data provide evidence that high-credit economies may not be especially volatile, but their business cycles tend to be more negatively skewed. In other words, leverage is associated with dampened business cycle volatility, but more spectacular crashes. Business cycle outcomes become more asymmetric in high-credit economies, echoing previous research on the asymmetry of cycles (McKay and Reis 2008).

A great deal of modern macroeconomic thought has relied on the small (and unrepresentative) sample of U.S. post-WW2 experience to formulate, calibrate, and test models of the business cycle, to calculate the welfare costs of fluctuations, and to analyze the benefits of stabilization policies. Yet the historical macroeconomic cross country experience is richer. An important contribution of this paper is to introduce a new comprehensive 
macro-financial historical database covering 17 advanced economies over the last 150 years. This considerable data collection effort that has occupied the better part of a decade, and involved a small army of research assistants.

We see two distinct advantages of using our data. First, models ostensibly based on universal economic mechanisms of the business cycle must account for patterns seen across space and time. Second, a very long-run perspective is necessary to capture enough "rare events" such as major financial dislocations and "macroeconomic disasters" to robustly analyze their impact on the volatility and persistence of real economic cycles.

We begin by deconstructing the financial hockey stick. The central development of the second half of the 2oth century is the rise of household credit, mostly of mortgages. Business credit has increased as well, but at a slower pace. Home ownership rates have climbed in almost every industrialized economy and, with them, real house prices. Private credit has increased much faster than income. Even though households are wealthier, private credit has grown faster even than the underlying wealth. Households are more levered than at any time in history.

Next we characterize the broad contours of the business cycle. Using a definition of turning points similar to many business cycle dating committees, such as the NBER's, we investigate features of the business cycle against the backdrop of the financial cycle. The associations we present between credit and the length of the expansion, and between deleveraging and the speed of the recovery, already hint at the deeper issues requiring further analysis. Economies grow more slowly and generally more stably post-WW2. Despite this apparent stability, financial crises since the fall of Bretton-Woods still occur with devastating regularity.

These broad contours lead us to a reevaluation of conventional stylized facts on business cycles using our newer and more comprehensive data, with a particular emphasis on real-financial interactions. The use of key statistical moments to describe business cycles goes back at least to the New Classical tradition which emerged in the 1970s 
(e.g., Kydland and Prescott 1990; Zarnowitz 1992; Backus and Kehoe 1992; Hodrick and Prescott 1997; Basu and Taylor 1999). Under this approach, the statistical properties of models are calibrated to match empirical moments in the data, such as means, variances, correlations, and autocorrelations.

In the final part of the paper, we examine key business cycle moments conditional on aggregate private credit levels. We find that rates of growth, volatility, skewness, and tail events all seem to depend on the ratio of private credit to income. Moreover, key correlations and international cross-correlations appear to also depend quite importantly on this leverage measure. Business cycle properties have changed with the financialization of economies, especially in the postwar upswing of the financial hockey stick. The manner in which macroeconomic aggregates correlate with each other has evolved as leverage has risen. Credit plays a critical role in understanding aggregate economic dynamics.

\section{A New Dataset for Macro-Financial Research}

The data featured in this paper represent one of its main contributions. We have compiled, expanded, improved, and updated a long-run macro-financial dataset that covers 17 advanced economies since 1870 on an annual basis. The first version of the dataset, unveiled in Jordà, Schularick and Taylor (2011) and Schularick and Taylor (2012), covered core macroeconomic and financial variables for 14 countries. The latest vintage covers 17 countries and 25 real and nominal variables. Among these, there are time series that had been hitherto unavailable to researchers, especially for key financial variables such as bank credit to the non-financial private sector (aggregate and disaggregate) and asset prices (equities and housing). We have now brought together in one place macroeconomic data that previously had been dispersed across a variety of sources. This dataset is publicly available at the NBER website.

Table 1 gives a detailed overview of the coverage of the latest vintage of the dataset, which gets updated on a regular basis as more data are unearthed and as time passes. 


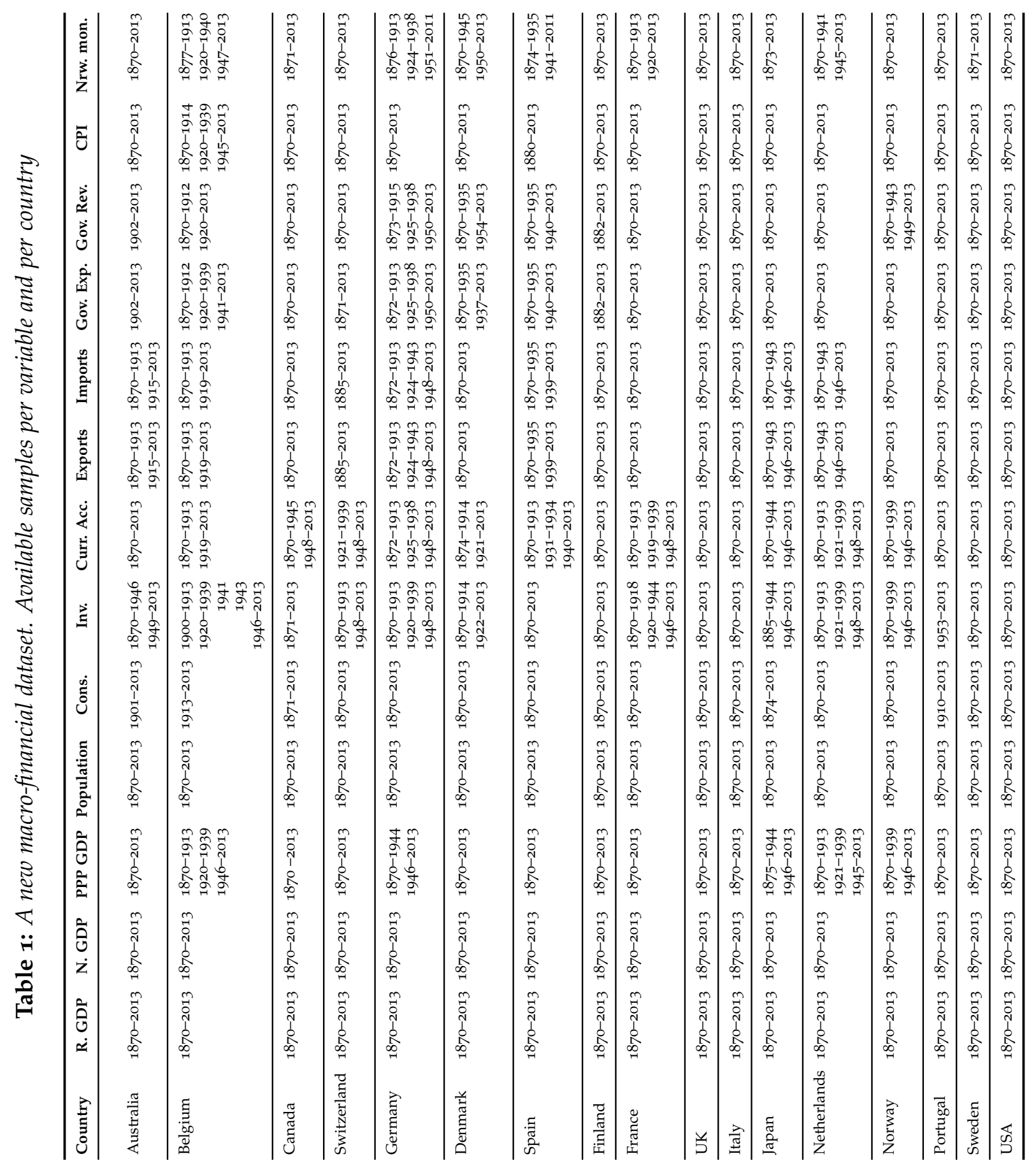




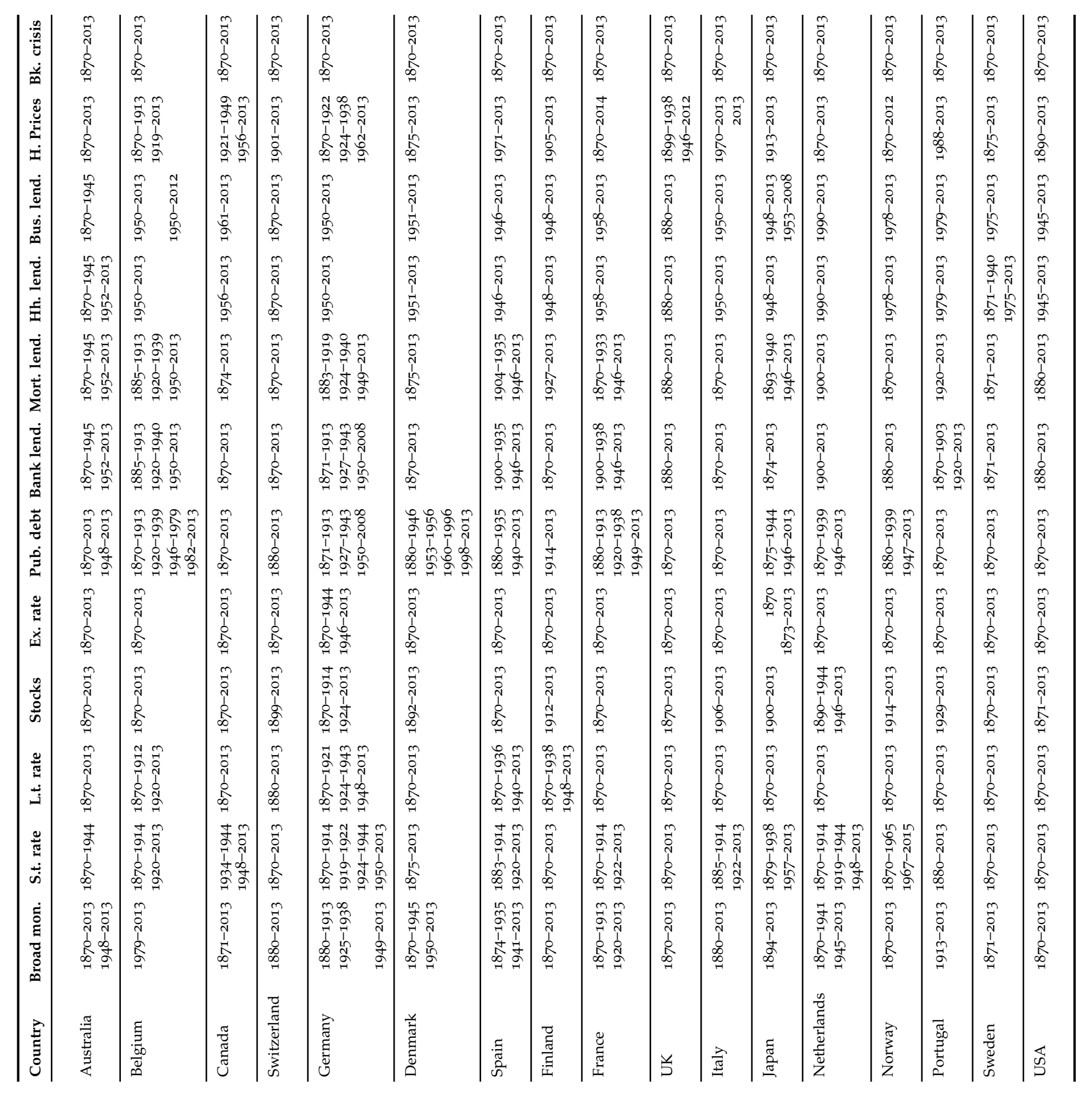


More details about the data construction appear in an extensive 100-page online appendix, which also acknowledges the support we received from colleagues all over the world.

In addition to country-experts, we consulted a broad range of sources, such as economic and financial history volumes and journal articles, and various publications of statistical offices and central banks. For some countries we extended existing data series from previous statistical work of financial historians or statistical offices. This was the case for Australia, Canada, Japan, and the United States. For other countries we chiefly relied on recent data collection efforts at central banks, such as for Denmark, Italy, and Norway. Yet in a non-negligible number of cases we had to go back to archival sources including documents from governments, central banks, and private banks. Typically, we combined information from various sources and spliced series to create long-run datasets spanning the entire 1870-2014 period for the first time.

\section{The Financial Hockey Stick}

The pivotal feature to emerge in the last 150 years of global macroeconomic history, as was first highlighted in Schularick and Taylor (2012), is the "hockey stick" pattern of private credit in advanced economies displayed in Figure 1. Focusing on private credit, defined henceforth as bank lending to the non-financial private sector, we can see that this variable maintained a relatively stable relationship with GDP and broad money until the 1970s. After an initial period of financial deepening in the 19th century, the average level of the credit-to-GDP ratio in advanced economies reached about 50\%-60\% around 1900. With the exception of the deep contraction in bank lending that was seen from the crisis of the Great Depression to WW2, the ratio was stable in this range until the 1970s.

Throughout this chapter we use the term "leverage" to denote the ratio of private credit to GDP. Although leverage is often used to designate the ratio of credit to the value of the underlying asset or net-worth, income-leverage is equally important as debt is serviced out of income. Net-worth-leverage is more unstable due to fluctuations in 
Figure 1: The financial hockey stick

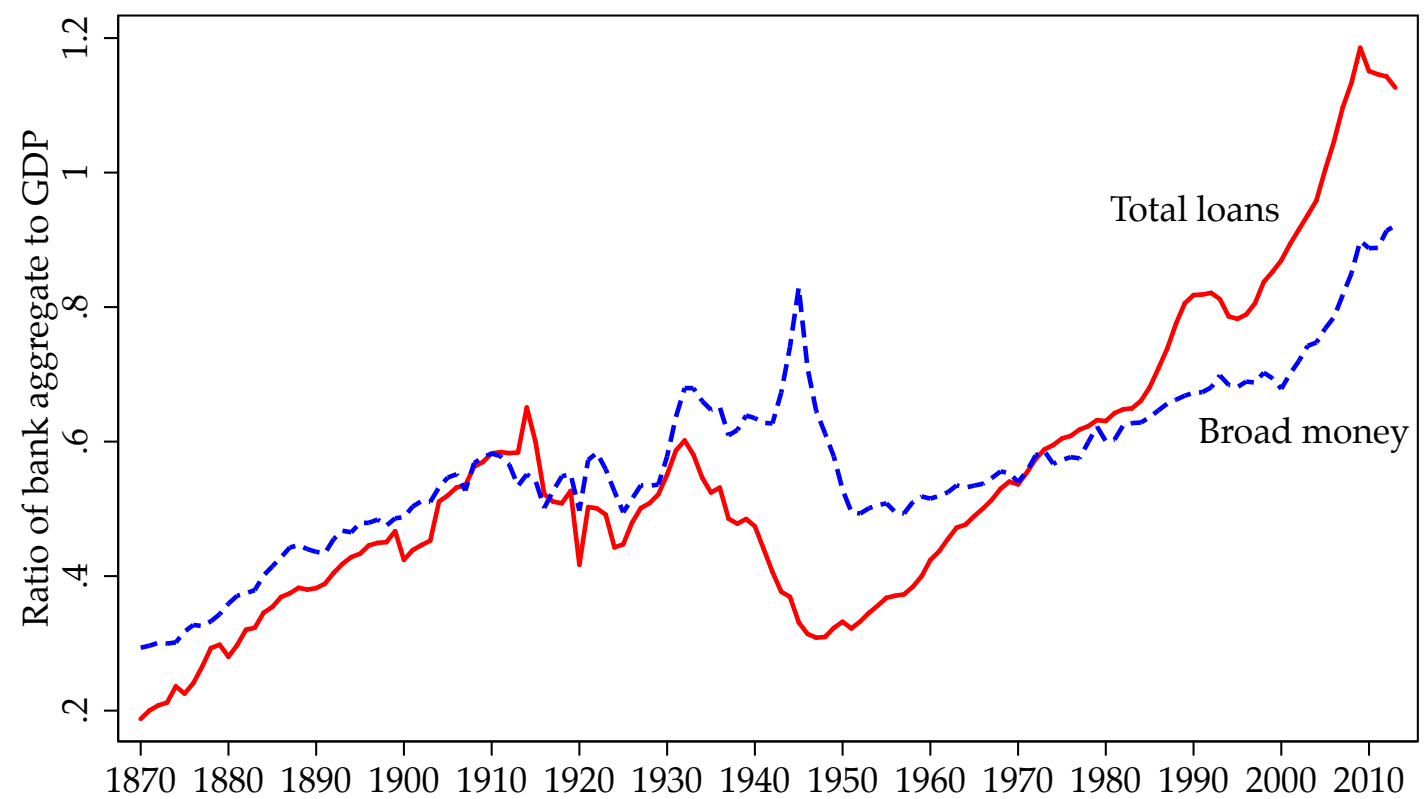

Notes: Total loans is bank lending to the non-financial private sector, Broad Money is M2 or similar broad measure of money, both expressed as a ratio to GDP averaged over the 17 countries in the sample. See text.

asset prices. For example, at the peak of the recent U.S. housing boom, ratios of debt to housing wealth signaled that household leverage was declining just as ratios of debt to income were exploding (Foote, Gerardi, and Willen 2012). Similarly, corporate balance sheets based on market values may mislead: in 2006-07 overheated asset values indicated robust capital ratios in major banks that were in distress or outright failure a few months later.

In the past four decades, the volume of private credit has grown dramatically relative to both output and monetary aggregates, as shown in Figure 1. The disconnect between private credit and (traditionally measured) monetary aggregates has resulted, in large part, from the shrinkage of bank reserves and the increasing reliance by financial institutions on non-monetary means of financing, such as bond issuance and inter-bank lending.

Private credit in advanced economies doubled relative to GDP between 1980 and 2009, increasing from $62 \%$ in 1980 to $118 \%$ in 2010 . The data also demonstrate the breathtaking 
Figure 2: Bank lending to business and households

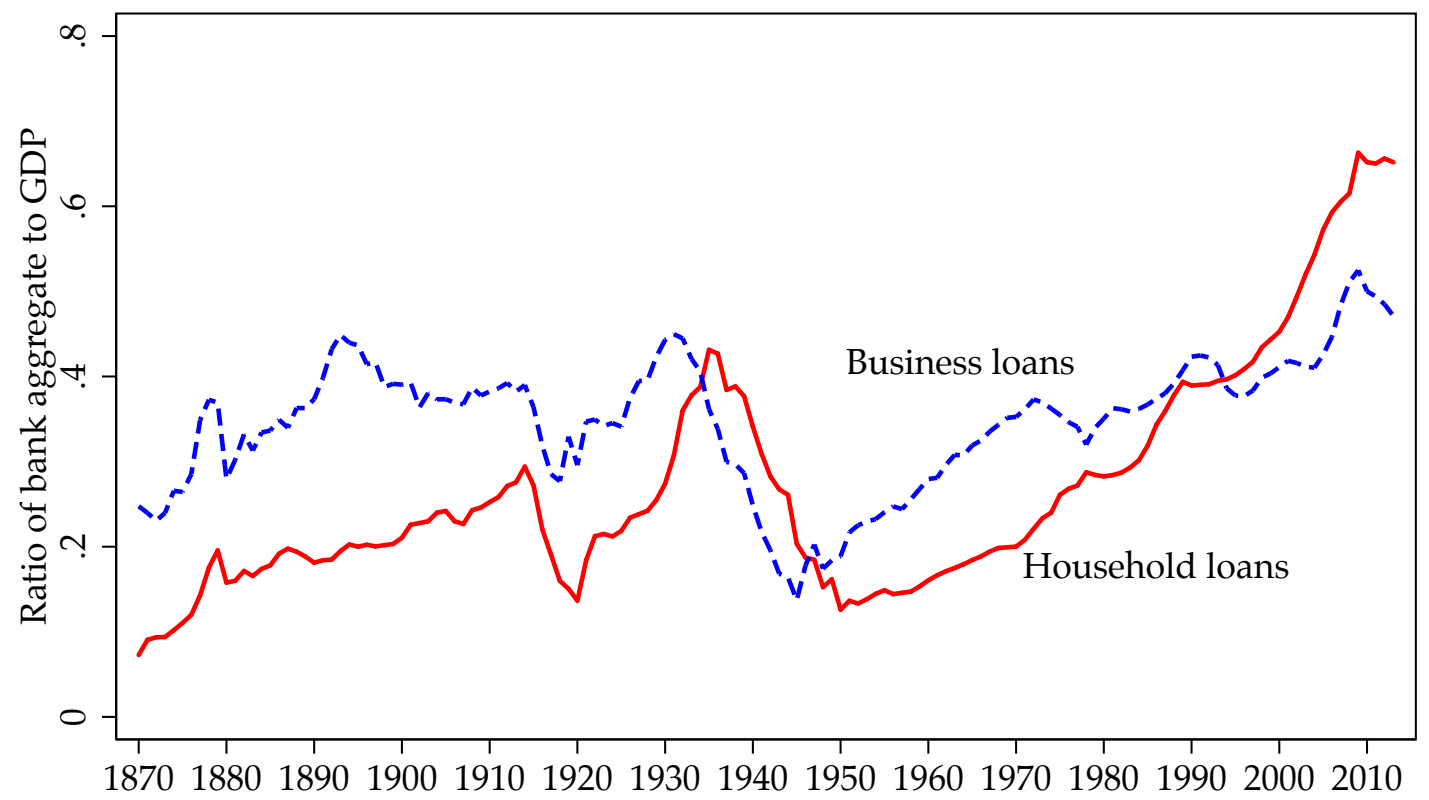

Notes: Business loans and Household loans are expressed as a ratio to GDP averaged over the 17 countries in the sample. See text.

surge of bank credit prior to the Global Financial Crisis in 2008. In a little more than 10 years, between the mid-1990s and 2008-09, the average bank credit to GDP ratio in advanced economies rose from a little under 80\% of GDP in 1995 to more than $110 \%$ of GDP in 2007. This 30 percentage points (pps) increase is likely to be a lower bound estimate as credit creation by the shadow banking system, of considerable size in the U.S. and to a lesser degree in the U.K., is excluded from our banking sector data.

What has been driving this great leveraging? A look at the disaggregated credit data, discussed in greater detail in Jordà, Schularick, and Taylor (2015), shows that the business of banking evolved substantially over the past 140 years. Figure 2 tracks the development of bank lending to the non-financial corporate sector and lending to households for our sample of 17 advanced economies. The ratio of business lending relative to GDP has remained relatively stable over the past century. On the eve of the global financial crisis, bank credit to corporates was not meaningfully higher than on the eve of WW1. 
Figure 3: The great mortgaging

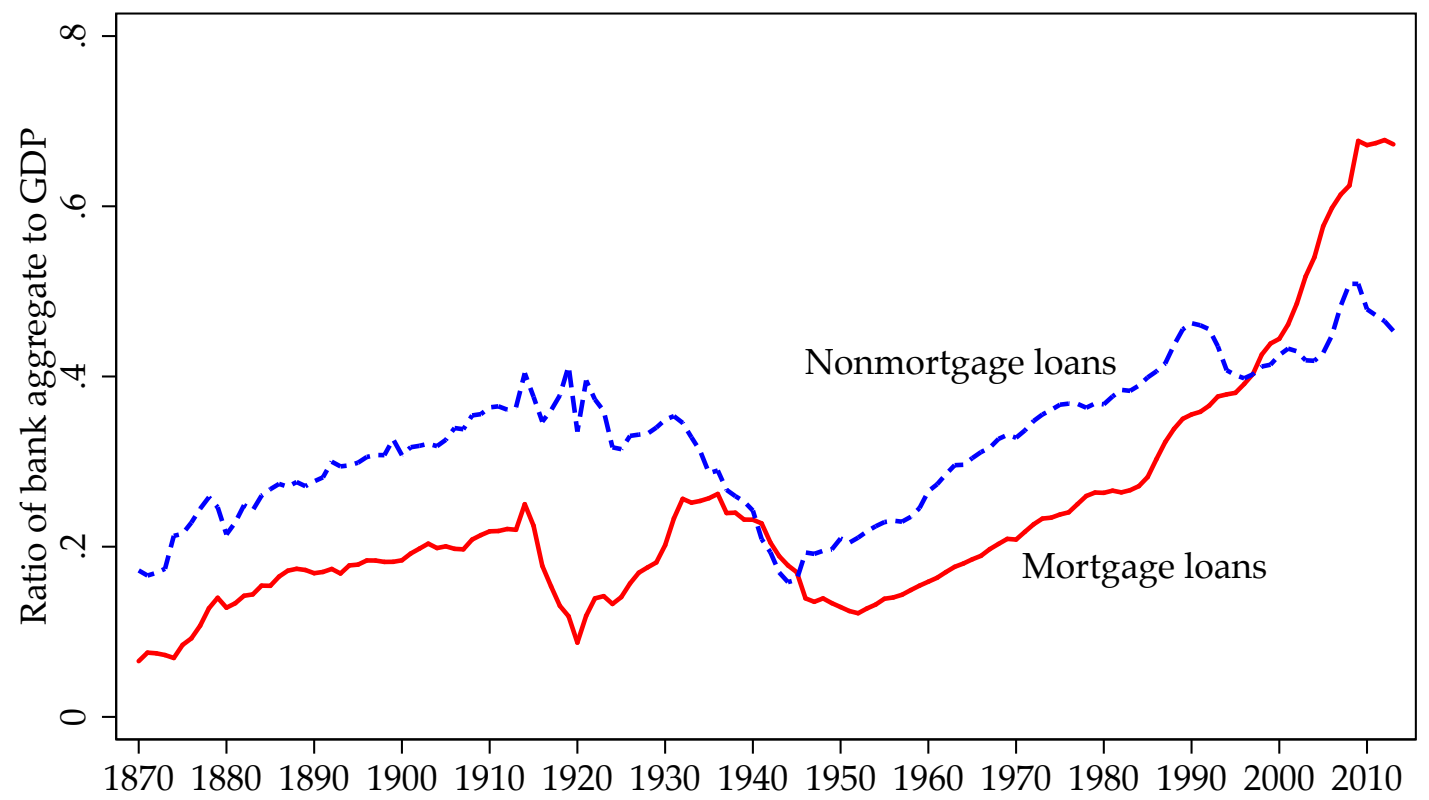

Notes: Mortgage loans and Nonmortgage loans are expressed as a ratio to GDP averaged over the 17 countries in the sample. Mortgage lending is to households and firms. Nonmortgage lending is unsecured lending primarily to businesses. See text.

Figure 3 tracks the evolution of mortgage and non-mortgage lending (mostly unsecured lending to businesses) relative to GDP from 1870 to the present. The graph demonstrates that mortgage borrowing has accelerated markedly in the advanced economies after WW2, a trend that is common to almost all individual economies. Mortgage lending to households accounts for the lion's share of the rise in credit to GDP ratios in advanced economies since 1980. To put numbers on these trends: at the turn of the 19th century, mortgage credit accounted for less than $20 \%$ of GDP on average. By 2010, mortgage lending represented $70 \%$ of GDP, more than three times the historical level at the beginning of the 2oth century. The main business of banks in the early 190os consisted of making unsecured corporate loans. Today, however, the main business of banks is to extend mortgage credit, often financed with short term borrowings. Mortgage loans now account for somewhere between one half and two thirds of the balance sheet of a typical advanced-country bank. 
Table 1: Change in bank lending to GDP ratios (multiple), 1960-2012

\begin{tabular}{lccccc}
\hline \hline Country & $\begin{array}{c}(1) \\
\text { Total lending }\end{array}$ & $\begin{array}{c}(2) \\
\text { Mortgage }\end{array}$ & $\begin{array}{c}(3) \\
\text { Non-mortgage }\end{array}$ & $\begin{array}{c}(4) \\
\text { Households }\end{array}$ & $\begin{array}{c}(5) \\
\text { Business }\end{array}$ \\
\hline Netherlands & 1.31 & 0.67 & 0.63 & - & - \\
Denmark & 1.18 & 0.98 & 0.19 & 0.75 & 0.43 \\
Australia & 1.12 & 0.72 & 0.40 & 0.78 & 0.34 \\
Spain & 1.11 & 0.78 & 0.33 & 0.70 & 0.41 \\
Portugal & 1.01 & 0.59 & 0.42 & - & - \\
USA* & 0.82 & 0.43 & 0.39 & 0.40 & 0.42 \\
USA & 0.21 & 0.17 & 0.04 & 0.13 & 0.07 \\
Sweden & 0.76 & 0.48 & 0.29 & - & - \\
Great Britain & 0.73 & 0.51 & 0.23 & 0.61 & 0.12 \\
Canada & 0.69 & 0.39 & 0.30 & 0.60 & - \\
Finland & 0.62 & 0.27 & 0.35 & 0.42 & 0.19 \\
Switzerland & 0.61 & 0.83 & -0.21 & 0.60 & 0.01 \\
Italy & 0.55 & 0.49 & 0.07 & 0.39 & 0.16 \\
France & 0.54 & 0.41 & 0.12 & 0.41 & 0.13 \\
Belgium & 0.51 & 0.32 & 0.19 & 0.34 & 0.17 \\
Germany & 0.49 & 0.28 & 0.21 & 0.20 & 0.29 \\
Norway & 0.40 & 0.53 & -0.13 & - & - \\
Japan & 0.38 & 0.41 & -0.03 & 0.28 & 0.10 \\
Average & 0.72 & 0.52 & 0.20 & 0.48 & 0.20 \\
Fraction of Average & 1.00 & 0.72 & 0.28 & 0.71 & 0.29 \\
\hline Notes: Col & & & 0.28 & \\
\hline
\end{tabular}

Notes: Column (1) reports the change in the ratio of total lending to GDP between 1960 to 2012 ordered from largest to smallest change. Columns (2) and (3) report the change due to real estate versus non-real estate lending. Columns (4) and (5) instead report the change due to lending to households versus lending to businesses. The USA entry with * includes credit market debt. Average reports the across country average for each column. Fraction of average reports the fraction of column (1) average explained by each category pair in columns (2) versus (3) and (4) versus (5). Notice that averages in columns (4) and (5) have been rescaled due to missing data so as to add up to total lending average reported in column (1). See text.

It is true that a substantial share of mortgage lending in the 19th by-passed the banking system and took the form of private lending. Privately held mortgage debt likely accounted for close to to percent of GDP at the beginning of the 2oth century. A high share of farm and non-farm mortgages was held outside banks in the U.S. and Germany too (Hoffman, Postel-Vinay, and Rosenthal 2000). A key development in the 2oth century was the subsequent transition of these earlier forms of "informal" real estate finance into the hands of banks and the banking system in the course of the 2oth century.

Moreover, even as we discuss the key aggregate trends, we do not mean to downplay 
the considerable cross-country heterogeneity in the data. Table 1 decomposes for each country the increase of total bank lending to GDP ratios over the past 50 years into growth of household debt and business debt as well as secured and unsecured lending. The percentage point change in the ratio of private credit to GDP in Spain was about three times higher than in Japan and more than twice as high as in Germany and Switzerland. However, it is equally clear from the table that the increase in the private credit-to-GDP ratio, as well as the central role played by mortgage credit to households, are both widespread phenomena.

The central question that we address in the remainder of the paper is to see if and how this secular growth of finance, the growing leverage of incomes, and the changes in the composition of bank lending have gone hand in hand with changes in the behavior of macroeconomic aggregates over the business cycle.

\section{Household Leverage, Home Ownership, and House Prices}

A natural question to ask is whether this surge in household borrowing occurred on the intensive or extensive margin. In other words, did more households borrow or did households borrow more? Ideally, we would have long-run household-level data to address this question, but absent such figures we can nonetheless infer some broad trends from our data. If households increased debt levels not only relative to income but also relative to asset values, this would raise greater concerns about the macroeconomic stability risks stemming from more highly leveraged household portfolios.

Historical data for the total value of the residential housing stock (structures and land) are only available for a number of benchmark years. We relate those to the total volume of outstanding mortgage debt to get an idea about long-run trends in real estate leverage ratios. Regarding sources, we combine data from Goldsmith's (1985) classic study of national balance sheets with recent estimates of wealth-to-income ratios by Piketty and Zucman (2013). Margins of error are wide, as it is generally difficult to separate the value 
Figure 4: Ratio of household mortgage lending to the value of the housing stock

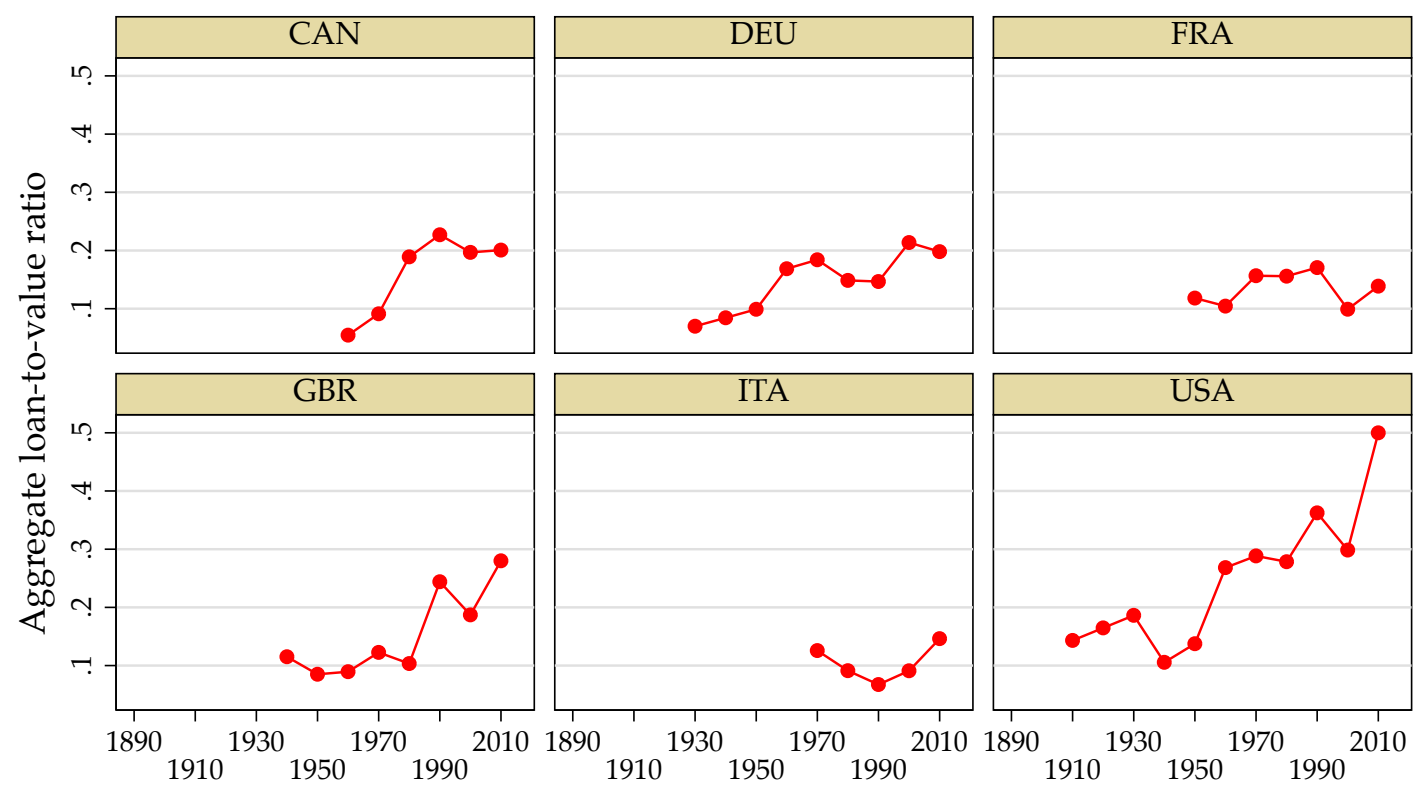

Notes: Approximations using reconstructed historical balance sheet data for benchmark years. Sources: Authors' calculations based on Piketty and Zucman (2013), Goldsmith (1985), and our own data.

of residential land from overall land for the historical period. We had to make various assumptions on the basis of available data for certain years.

Figure 4 shows that the ratio of household mortgage debt to the value of real estate has increased considerably in the United States and the United Kingdom in the past three decades. In the United States mortgage debt to housing value climbed from $28 \%$ in 1980 to over $40 \%$ in 2013 , and in the United Kingdom from slightly more than $10 \%$ to $28 \%$. A general upward trend in the second half of the 2oth century is also clearly discernible in a number of other countries.

Figure 5 shows that this upward trend in debt-to-asset ratios coincided with a surge in global house prices, as discussed in Knoll, Schularick, and Steger (2015). Real house prices exhibit a hockey-stick pattern just like the credit aggregates. Having stayed constant for the first century of modern economic growth, global house prices embarked on a steep ascent in the second half of the 2oth century and tripled within three decades of the onset of large-scale financial liberalization. 
Figure 5: Real house prices, 1870-2013

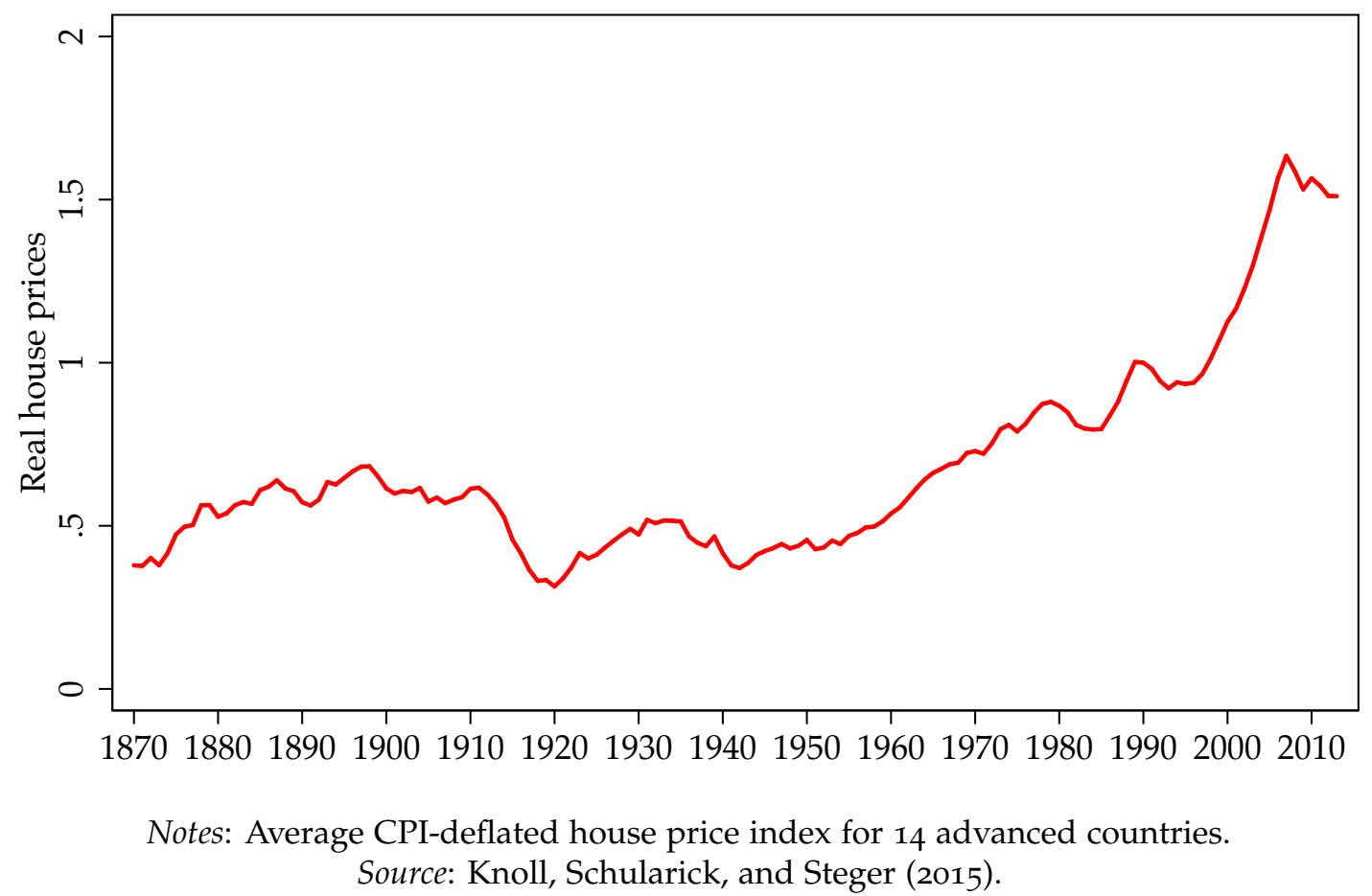

A second trend is equally important: the extensive margin of mortgage borrowing also played a role. Table 2 demonstrates that the rise in economy-wide leverage has financed a substantial expansion of home ownership in many countries. The idea that home ownership is an intrinsic part of the national identity is widely accepted in many countries, but in most cases it is a relatively recent phenomenon. Before WW2, home ownership was not widespread. In the U.K. for instance, home ownership rates were in the low $20 \%$ range in the 1920 . In the U.S., the homeownership rate did not cross the $50 \%$ bar until after WW2, when generous provisions in the G.I. bill helped push it up by about to percentage points. For the sample average, home ownership rates were around $40 \%$ after WW2. By the 2000s, they had risen to $60 \%$ - an increase of about 20 percentage points in the course of the past half century. In some countries such as Italy we observe that homeownership rates doubled after WW2. In others, such as France and the U.K. they went up by nearly $50 \%$.

Quantitative evidence on the causes of such pronounced differences in homeownership 
Table 2: Home ownership rates in the 2oth century (owner-occupied share of units, percent)

\begin{tabular}{lcccccccc}
\hline \hline & Canada & Germany & France & Italy & Switzerland & U.K. & U.S. & Average \\
\hline 1900 & & & & & & & 47 & \\
1910 & & & & & & & 46 & \\
1920 & & & & & & & 46 & \\
1930 & & & & & & 32 & 44 & \\
1940 & 57 & 39 & 38 & 40 & 37 & 32 & 47 & 43 \\
1950 & 66 & 34 & 41 & 45 & 34 & 42 & 62 & 46 \\
1960 & 66 & 36 & 45 & 50 & 29 & 50 & 63 & 48 \\
1970 & 60 & 39 & 47 & 59 & 30 & 58 & 64 & 51 \\
1980 & 63 & 59 & 57 & 31 & 68 & 64 & 55 \\
1990 & 63 & 65 & 56 & 80 & 35 & 69 & 67 & 60 \\
2000 & 66 & 45 & 58 & 82 & 37 & 64 & 65 & 60 \\
2013 & 69 & 45 & & & & & & \\
\hline \hline
\end{tabular}

Sources: See Jordà, Schularick, and Taylor (2016a), Table 3.

rates between advanced economies is still scarce. Differences in rental regulation, tax policies, and other forms of government involvement, as well as ease of access to mortgage finance and historical path dependencies, likely all played a role. Studies in historical sociology, such as Kohl (2014), explain differences in homeownership rates between the U.S., Germany, and France, as a consequence of the dominant role played by the organization of urban housing markets. In all countries, the share of owner-occupied housing is roughly comparable in rural areas; rather, the stark differences in aggregate ownership rates are mainly a function of the differences in the organization of urban housing across countries.

Divergent trajectories in housing policy also matter. In the U.S., the Great Depression was the main catalyst for new policies aimed at facilitating home ownership. Yet government interventions in the housing market remained an important part of the policy landscape after WW2 or even intensified. In the U.S. case, the Veterans Administration (VA) was established through the G.I. Bill in 1944. The VA guaranteed loans with high loan-to-value ratios over $90 \%$, with some loans passing the $100 \%$ loan-to-value mark (Fetter 2013). $40 \%$ of all mortgages were federally subsidized in the 1950 . The G.I. Bill is credited with explaining up to one quarter of the post-WW2 increase in the rate of home 
ownership. In many European countries, the government already took a more active role in the housing sector following World War I. But European housing policies tended to focus on public construction and ownership of housing whereas in the U.S. the emphasis was on financial support for individual homeownership through the subsidization of mortgage interest rates or public loan guarantees.

The experience with the Great Depression was also formative with regard to the growing role of the state in regulating and ultimately backstopping the financial sector. The most prominent innovation was deposit insurance. In the U.S., deposit insurance was introduced as part of the comprehensive Banking Act of 1933, commonly known as the Glass-Steagall Act. Some European countries like Switzerland and Belgium also introduced deposit insurance scheme in the 1930s. In the majority of European countries deposit insurance was introduced in the decades following World War II, albeit with considerable institutional variety (Demirgüç-Kunt et al. 2013). However, different American and European approaches to the organization of deposit insurance are observable. This is because, at least in the early stages, European deposit insurance schemes relied chiefly on industry arrangements. The U.S. stands out as the first country that committed the tax payer to backstopping the banking system.

A common effect of the depression, however, was that in almost all countries the role of the state as a financial player increased. After the devastating consequences of a dysfunctional financial sector had become apparent during the 1930s, the sector was kept on a short leash. Directly or indirectly, the state became more intertwined with finance. Among the major economies, Germany clearly went to one extreme by turning the financial sector into little more than a handmaiden of larger policy goals in the 1930s. In doing so, it inadvertently pioneered various instruments of financial repression (e.g., channeling deposits into government debt) that, in one form or the other, became part of the European financial policy toolkit after World War II. For instance, France ran a tight system of controls on savings flows in the postwar decades (Monnet 2014). 
Figure 6: Leverage - loans, wealth, and income in U.S., U.K., France, and Germany, averages

(a) Total lending and total wealth

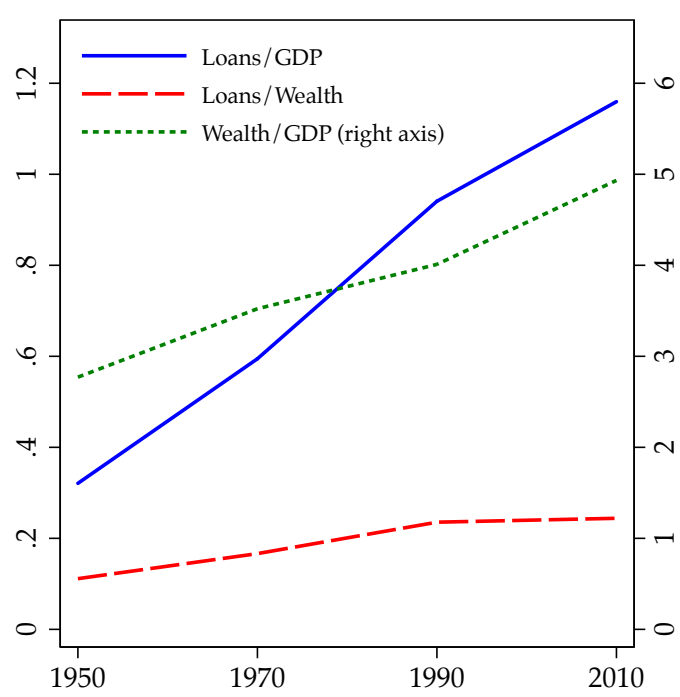

(b) Mortgage lending and housing wealth

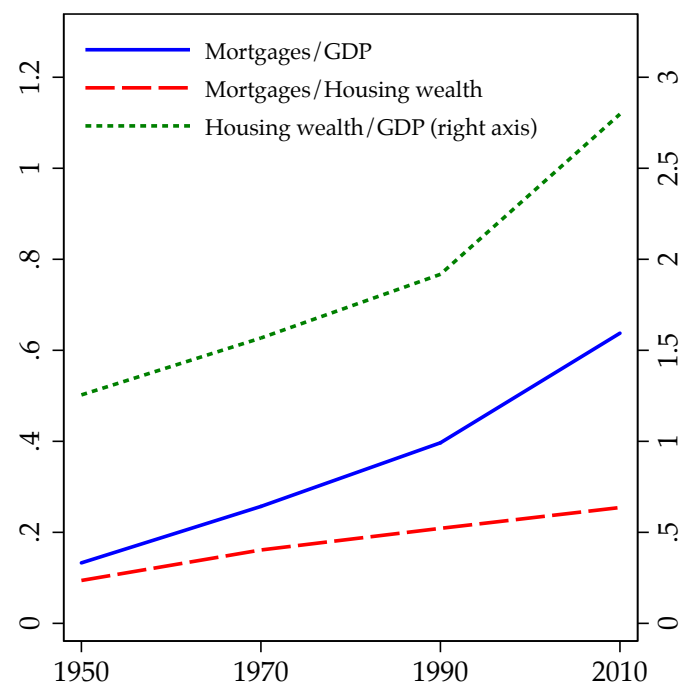

Notes: Variables expressed as ratios. Right-hand side axes always refer to wealth over GDP ratios. Data on wealth and housing wealth available online at http:\piketty.pse.ens.fr/en/capitalisback from Piketty and Zucman (2013). All other data collected by the authors.

In this long-run context, can we assay in any quantitative way the role played by debt-income and debt-wealth changes over time in the evolution of leverage? To this end, Figure 6 and Table 3 provide comparisons of borrowing, wealth, and GDP. The figure displays three grand ratios for the average of the U.S., U.K., France, and Germany over the post-WW2 era in 20-year windows. Panel (a) displays total private lending to the non-financial sector (total lending) as a ratio to GDP (solid line); total lending as a ratio to total wealth (dashed line); and total wealth as a ratio to GDP (dotted line). Panel (b) of the same figure presents a similar but more granular decomposition to focus on the housing market: the ratio of mortgages to GDP (solid thick line); the ratio of mortgages to housing wealth (dashed line); and the ratio of housing wealth to GDP (dotted line). Data on wealth come from Piketty and Zucman (2013) and are available only for selected countries and a limited sample.

Similarly, Table 3 displays these three grand ratios, again organized by the same principles: panel (a), for all categories of lending and wealth; and panel (b), for mortgages 
Table 3: Leverage - grand ratios for loans, wealth, and GDP in U.S., U.K., France, and Germany, averages and by country

\begin{tabular}{|c|c|c|c|c|c|c|c|c|}
\hline & \multicolumn{4}{|c|}{$\begin{array}{l}\text { (a) All wealth, } \\
\text { all loans }\end{array}$} & \multicolumn{4}{|c|}{$\begin{array}{l}\text { (b) Housing wealth, } \\
\text { mortgage loans }\end{array}$} \\
\hline & 1950 & 1970 & 1990 & 2010 & 1950 & 1970 & 1990 & 2010 \\
\hline \multicolumn{9}{|l|}{ Loans/GDP } \\
\hline U.S. & 0.55 & 0.90 & 1.23 & 1.65 & 0.30 & 0.44 & 0.63 & 0.92 \\
\hline U.K. & 0.23 & 0.30 & 0.88 & 1.07 & 0.09 & 0.15 & 0.38 & 0.65 \\
\hline France & 0.32 & 0.59 & 0.79 & 0.98 & 0.10 & 0.19 & 0.30 & 0.52 \\
\hline Germany & 0.19 & 0.59 & 0.87 & 0.95 & 0.03 & 0.25 & 0.27 & 0.46 \\
\hline Average & 0.32 & 0.59 & 0.94 & 1.16 & 0.13 & 0.26 & 0.40 & 0.64 \\
\hline \multicolumn{9}{|c|}{ Loans/Wealth } \\
\hline U.S. & 0.14 & 0.23 & 0.29 & 0.38 & 0.18 & 0.26 & 0.35 & 0.47 \\
\hline U.K. & 0.11 & 0.09 & 0.19 & 0.20 & 0.08 & 0.11 & 0.19 & 0.21 \\
\hline France & 0.11 & 0.16 & 0.21 & 0.16 & 0.08 & 0.12 & 0.16 & 0.13 \\
\hline Germany & 0.08 & 0.19 & 0.24 & 0.23 & 0.04 & 0.17 & 0.14 & 0.19 \\
\hline Average & 0.11 & 0.17 & 0.24 & 0.24 & 0.09 & 0.16 & 0.21 & 0.25 \\
\hline \multicolumn{9}{|l|}{ Wealth/GDP } \\
\hline U.S. & 3.80 & 4.00 & 4.19 & $4 \cdot 31$ & 1.70 & 1.71 & 1.83 & 1.94 \\
\hline U.K. & 2.08 & $3 \cdot 33$ & 4.62 & 5.23 & 1.11 & 1.44 & 1.99 & 3.03 \\
\hline France & 2.91 & 3.63 & 3.68 & 6.05 & 1.30 & 1.64 & 1.94 & 3.83 \\
\hline Germany & 2.29 & 3.13 & 3.55 & 4.14 & 0.91 & 1.48 & 1.91 & 2.39 \\
\hline Average & 2.77 & 3.52 & 4.01 & 4.93 & 1.26 & 1.57 & 1.92 & 2.80 \\
\hline
\end{tabular}

Sources: Piketty and Zucman (2013). Excel tables are available online at http://piketty.pse.ens.fr/ en/capitalisback. Excel Tables for DEU, FRA, USA, GBR, Tables 6f, column (3) "national wealth" for wealth and column (4) "including housing" for national housing wealth. 1950 data on wealth for France refers to 1954. Loans refers to total bank loans to the private, non-financial sector. Data on bank loans and mortgages, and data on GDP collected by the authors. Ratios calculated in local currency.

and housing wealth. The table provides data for the U.S., U.K., France, and Germany as well as the average across all four which is used to construct Figure 6. It should be clear from the definition of these three grand ratios that our concept of leverage, defined as the ratio of lending to GDP, is mechanically linked to the ratio of lending to wealth times the ratio of wealth to GDP.

Figure 6 and panel (b) of Table 3 in particular, give a compelling reason to focus on the ratio of mortgages to GDP rather than as a ratio to housing wealth. In the span of the 
last 60 years, the ratio of mortgages to GDP is nearly six times larger; whereas, measured against housing wealth, mortgages have almost tripled. Of course, the reason for this divergence is the accumulation of housing wealth over the this period, which has more than doubled when measured against GDP.

Summing up, our study of the financial hockey stick has yielded three core insights. First, the sharp rise of aggregate credit-to-income ratios is linked mainly to rising mortgage borrowing by households. Bank lending to the business sector has played a subsidiary role in this process and has remained roughly constant relative to income. Second, the rise in aggregate mortgage borrowing relative to income has been driven by substantially higher aggregate loan-to-value ratios against the backdrop of house price gains that have outpaced income growth in the final decades of the 2oth century. Lastly, the extensive margin of increasing home ownership rates mattered too. In many countries, home ownership rates have increased considerably. The financial hockey stick can therefore be understood as a corollary of more highly leveraged homeownership against substantially higher asset prices.

\section{Expansions, Recessions, and Credit}

What are the key features of business and financial cycles in advanced economies over the last 150 years? A natural way to tackle this question is to divide our annual frequency sample into periods of real GDP per capita growth or expansions, and years of real GDP per capita decline or recessions. At annual frequency, this classification is roughly equivalent to the dating of peaks and troughs routinely issued by business cycle committees, such as the NBER's for the U.S. We will use the same approach to discuss cycles based on real credit per capita (measured by our private credit variable deflated with the CPI index). This will allow us to contrast the GDP and credit cycles.

This characterization of the cycle does not depend on the method chosen to detrend the data, or on how potential output and its dynamics are determined. Rather, it is 
based on the observation that in economies where the capital stock and population are growing, negative economic growth represents a sharp deterioration in business activity, well beyond the vagaries of random noise. ${ }^{1}$

In a recent paper McKay and Reis (2008) reach back to Mitchell (1927) to discuss two features of the business cycle, "brevity" and "violence" in Mitchell's words. ${ }^{2}$ Harding and Pagan (2002) provide more operational definitions that are roughly equivalent. In their paper, brevity refers to the duration of a cyclical phase, expressed in years. Violence refers to the average rate of change per year. It is calculated as the overall change during a cyclical phase divided by its duration and expressed as percent change per year.

These simple statistics, duration (or violence) and rate (or brevity) can be used to summarize the main features of business and credit cycles. Table 4 show two empirical regularities: (1) the growth cycles in real GDP (per capita) and in real credit growth using turning points in GDP; and (2) the same comparison between GDP and credit, this time using turning points in credit. In both cases, the statistics are reported as an average for the full sample of 17 advanced economies, and for the Pre- and Post-WW2 subsamples.

What are the features of the modern business cycle? Output expansions have almost tripled after WW2, from 3.1 to 8.6 years, whereas credit expansions have roughly doubled, from 4.2 to 8.3 years. On the other hand, recessions tend to be briefer and roughly similar before and after WW2. Moreover, there is little difference (certainly no statistically significant difference) between the duration of output and credit based recessions. The elongation of output expansions after WW2 coincides with a reduction in the rate of growth, from 4.1 to 3.0 percent per annum (p.a.), accompanied with a reduction in volatility. Expansions are more gradual and less volatile. A similar phenomenon is visible in recessions, where the rate of decline essentially halves from $2.9 \%$ p.a. pre-WW2 to $1.7 \%$ p.a. post-WW2.

\footnotetext{
${ }^{1}$ We use a per capita measure of real GDP here to account for cyclical variations in economic activity across a wide range of historical epochs which vary widely in the background rate of population growth.

2"Business contractions appear to be briefer and more violent than business expansions" (Mitchell 1927, 333).
} 
Table 4: Duration and rate of change - GDP versus credit cycles

\begin{tabular}{|c|c|c|c|c|c|c|}
\hline & \multicolumn{3}{|c|}{ Expansions } & \multicolumn{3}{|c|}{ Recessions } \\
\hline & Full & Pre-WW2 & Post-WW2 & Full & Pre-WW2 & Post-WW2 \\
\hline \multicolumn{7}{|l|}{ GDP-based cycles } \\
\hline Duration (years) & $\begin{array}{c}5 \cdot 1 \\
(5 \cdot 5)\end{array}$ & $\begin{array}{c}3.1 \\
(2.7)\end{array}$ & $\begin{array}{l}8.6 \\
(7.2)\end{array}$ & $\begin{array}{l}1.5 \\
(0.9)\end{array}$ & $\begin{array}{l}1.6 \\
(1.0)\end{array}$ & $\begin{array}{l}1.4 \\
(0.8)\end{array}$ \\
\hline \multicolumn{7}{|l|}{ Rate (\% p.a) } \\
\hline GDP & $\begin{array}{c}3 \cdot 7 \\
(2 \cdot 3)\end{array}$ & $\begin{array}{c}4.1 \\
(2.5)\end{array}$ & $\begin{array}{c}3.0 \\
(1.7)\end{array}$ & $\begin{array}{l}-2.5 \\
(2.5)\end{array}$ & $\begin{array}{l}-2.9 \\
(2.8)\end{array}$ & $\begin{array}{l}-1.7 \\
(1.5)\end{array}$ \\
\hline Credit & $\begin{array}{c}4.6 \\
(10)\end{array}$ & $\begin{array}{c}4.7 \\
(13)\end{array}$ & $\begin{array}{c}4 \cdot 5 \\
(4 \cdot 3)\end{array}$ & $\begin{array}{c}2.2 \\
(8.0)\end{array}$ & $\begin{array}{c}3.7 \\
(8.9)\end{array}$ & $\begin{array}{c}\text { o.o } \\
(5.7)\end{array}$ \\
\hline $\begin{array}{l}p \text {-value } H_{0}: G D P=\text { Credit } \\
\text { Observations }\end{array}$ & $\begin{array}{l}0.10 \\
315\end{array}$ & $\begin{array}{l}0.46 \\
203\end{array}$ & $\begin{array}{c}0.00 \\
112\end{array}$ & 0.00 & $\begin{array}{l}0.00 \\
209\end{array}$ & 0.00 \\
\hline \multicolumn{7}{|l|}{ Credit-based cycles } \\
\hline Duration (years) & $\begin{array}{c}6.1 \\
(6.4)\end{array}$ & $\begin{array}{c}4.2 \\
(4 \cdot 3)\end{array}$ & $\begin{array}{c}8.3 \\
(7.6)\end{array}$ & $\begin{array}{c}1.9 \\
(1.5)\end{array}$ & $\begin{array}{c}1.7 \\
(1.5)\end{array}$ & $\begin{array}{c}2.0 \\
(1.5)\end{array}$ \\
\hline \multicolumn{7}{|l|}{ Rate (\% p.a.) } \\
\hline GDP & $\begin{array}{c}2.1 \\
(3.1)\end{array}$ & $\begin{array}{c}1.6 \\
(3.7)\end{array}$ & $\begin{array}{l}2.8 \\
(2.0)\end{array}$ & $\begin{array}{l}1.2 \\
(3 \cdot 3)\end{array}$ & $\begin{array}{l}1.5 \\
(3.8)\end{array}$ & $\begin{array}{c}0.8 \\
(2.4)\end{array}$ \\
\hline Credit & $\begin{array}{l}7.0 \\
(5.6)\end{array}$ & $\begin{array}{c}7 \cdot 9 \\
(6.8)\end{array}$ & $\begin{array}{c}5 \cdot 9 \\
(3 \cdot 5)\end{array}$ & $\begin{array}{l}-5.0 \\
(6.7)\end{array}$ & $\begin{array}{l}-6.5 \\
(8.4)\end{array}$ & $\begin{array}{l}-3 \cdot 3 \\
(3.1)\end{array}$ \\
\hline $\begin{array}{l}p \text {-value } H_{0}: G D P=\text { Credit } \\
\text { Observations }\end{array}$ & 0.00 & 0.00 & 0.00 & 0.00 & 0.00 & 0.00 \\
\hline Ubservations & 240 & 130 & 110 & 254 & 141 & 113 \\
\hline
\end{tabular}

Notes: GDP-based cycles refers to turning points determined by real GDP per capita. Credit-based cycles refers to turning points determined by real bank lending per capita. Duration refers to the number of years that each phase between turning points lasts. Rate refers to the annual rate of change between turning points in percent per year. Standard errors in parenthesis. $p$-value $H_{0}: G D P=$ Credit refers to test of the null that the rate of growth for real GDP per capita and real bank lending per capita are the same. See text.

Interestingly, the behavior of credit is very similar across eras but only during expansions. The rate of credit growth is remarkably stable through the entire period, from $4.7 \%$ pre-WW2 to $4.5 \%$ post-WW2. Credit seems to grow on a par with output before WW2 (the null cannot be rejected formally with a $p$-value of 0.46 ), whereas it grows nearly 1.5 percentage points faster than output post-WW2, a statistically significant difference (with a $p$-value below 0.01). In recessions, credit growth continues almost unabated in the pre-WW2 era (it declines from $4.7 \%$ p.a. in expansion to $3.7 \%$ p.a. in recession) but it grinds to a halt post-WW2 (from $4.5 \%$ p.a. in expansion to $\%$ p.a. in recession). 
Credit cycles do not exactly align with business cycles. This can be seen via the concordance index, defined as the average fraction of the time two variables spend in the same cyclical phase. This index equals 1 when cycles from both variables exactly match, that is, both are in expansion and in recession at a given time. The index is o if one of the variables is in expansion and the other is in recession, or vice versa.

Using this definition, before WW2 the concordance index is 0.61 suggesting a weak link between output and credit cycles. If output is in expansion, it is almost a coin toss whether credit is in expansion or in recession. However, post-WW2 the concordance index rises to 0.79 . This value is similar, for example, to the concordance index between output and investment cycles post-WW2.

Another way to see the increased synchronization between output and credit cycles is made clear in the bottom panel of Table 4 . The duration of credit expansions is about 1 year longer than the duration of GDP expansions pre-WW2, but roughly the same length post-WW2. Credit recessions are slightly longer than GDP recessions (by about 3-months on average) but not dramatically different. Thus both types of cycle exhibit considerable asymmetry in duration between expansion and recession phases.

As we can also see in Table 4, things are quite different when considering the average rate of growth during each expansion/recession phase. Whereas credit grew in expansion at nearly $8 \%$ p.a. pre-WW2, output grew at only 1.6\% p.a. After WW2, the tables are turned. Credit grows 2 percentage points slower but output grows almost twice as fast. On average, there is a much tighter connection between growth in the economy and growth in credit after WW2. Perhaps the more obvious takeaway is that credit turns out to be a more violent variable than GDP. Credit expansions and recessions exhibit wilder swings than GDP expansions and recessions.

These results raise some intriguing questions. What is behind the longer duration of expansions since WW2? What connection, if any, does this phenomenon have to do with credit? In previous research (Jordà, Schularick, and Taylor 2013), we showed that rapid 
growth of credit in the expansion is usually associated with deeper and longer lasting recessions, everything else equal. But what about the opposite, does rapid deleveraging in the recession lead to faster and brighter recoveries? And what is the relationship between credit in the expansion and its duration? Does more rapid deleveraging make the recession last longer? In order to answer some of these questions, we stratify the results by credit growth in the next two tables.

In Table 5 we stratify results depending on whether credit in the current expansion is above or below country-specific means and examine how this correlates with the current expansion and subsequent recession. Consistent with the results reported in our previous work (Jordà, Schularick, and Taylor 2013), rapid credit growth during the expansion is associated with a deeper recession, especially in the post-WW2 era. Compare here rates of decline per annum, $-1.8 \%$ versus $-1.6 \%$ with the recession lasting about 5 months more. However, it is also true that the expansion itself lasts about 3 years longer (and at a higher per annum rate of growth). In the pre-WW2, expansions last about 9 months longer when credit grows above average and there is little difference in the brevity of recessions.

The shaft and the blade of our financial hockey stick thus also appear to mark a shift in the manner in which credit and the economy interact. Since WW2, rapid credit growth is associated with longer lasting expansions (by about 3 years) and more rapid rates of growth (3.0\% versus $2.7 \%$ ). However, when the recession hits, the economic slowdown is also deeper. In terms of a crude trade-off, periods with above mean credit growth are associated with an additional $12 \%$ growth in output relative to a $1 \%$ loss during the following recession, a net gain of nearly $11 \%$ over the 12 years that the entire cycle lasts (expansion plus recession), that is, almost an extra $1 \%$ per year.

As a complement to these results, Table 6 provides a similar stratification based on whether credit grows above or below country-specific means during the current recession, and then examines the current recession and the subsequent expansion. A High Credit bin here means that credit grew above average during the recession (or that there was less 
Table 5: Duration and rate of real GDP cycles — stratified by credit growth in current expansion

\begin{tabular}{|c|c|c|c|c|c|c|}
\hline & \multicolumn{3}{|c|}{ Current Expansion } & \multicolumn{3}{|c|}{ Subsequent Recession } \\
\hline & Full Sample & Pre-WW2 & Post-WW2 & Full Sample & Pre-WW2 & Post-WW2 \\
\hline \multicolumn{7}{|l|}{ Duration (years) } \\
\hline $\begin{array}{l}\text { High Credit } \\
\text { Expansion }\end{array}$ & $\begin{array}{c}6.3 \\
(6.5)\end{array}$ & $\begin{array}{c}3.4 \\
(3.2)\end{array}$ & $\begin{array}{l}10.2 \\
(7.1)\end{array}$ & $\begin{array}{l}1.6 \\
(0.9)\end{array}$ & $\begin{array}{c}1.5 \\
(0.8)\end{array}$ & $\begin{array}{c}1.7 \\
(0.9)\end{array}$ \\
\hline $\begin{array}{l}\text { Low Credit } \\
\text { Expansion }\end{array}$ & $\begin{array}{l}3.8 \\
(3.6)\end{array}$ & $\begin{array}{c}2.6 \\
(1.9)\end{array}$ & $\begin{array}{l}7.0 \\
(6.6)\end{array}$ & $\begin{array}{l}1.5 \\
(0.8)\end{array}$ & $\begin{array}{l}1.6 \\
(1.0)\end{array}$ & $\begin{array}{l}1.3 \\
(0.5)\end{array}$ \\
\hline \multicolumn{7}{|l|}{ Rate (\% p.a.) } \\
\hline $\begin{array}{l}\text { High Credit } \\
\text { Expansion }\end{array}$ & $\begin{array}{c}3 \cdot 3 \\
(2.0)\end{array}$ & $\begin{array}{c}3.8 \\
(2.3)\end{array}$ & $\begin{array}{c}3.0 \\
(1.5)\end{array}$ & $\begin{array}{l}-2.4 \\
(2.3)\end{array}$ & $\begin{array}{l}-3.0 \\
(2.8)\end{array}$ & $\begin{array}{l}-1.8 \\
(1.3)\end{array}$ \\
\hline $\begin{array}{l}\text { Low Credit } \\
\text { Expansion }\end{array}$ & $\begin{array}{c}4.1 \\
(2.5)\end{array}$ & $\begin{array}{c}4.7 \\
(2.7)\end{array}$ & $\begin{array}{c}2.7 \\
(1.4)\end{array}$ & $\begin{array}{l}-2.7 \\
(2.8)\end{array}$ & $\begin{array}{l}-3 \cdot 3 \\
(3.2)\end{array}$ & $\begin{array}{l}-1.6 \\
(1.7)\end{array}$ \\
\hline Observations & 271 & 164 & 107 & 261 & 153 & 108 \\
\hline
\end{tabular}

Notes: Rate refers to the annual rate of change between turning points. Duration refers to the number of years that each phase between turning points lasts. High/Low Credit refers to whether credit growth during the expansion is above/below country specific means. Recessions sorted by behavior of credit (above/below country-specific mean) in the preceding expansion. Standard errors in parenthesis. See text.

deleveraging, in some cases). The Low Credit bin is associated with recessions in which credit grew below average or there was more deleveraging, in some cases.

On a first pass, for the post-WW2 era only, low credit growth in a recession is associated with a slightly deeper recession (less violent, but longer lasting, for a total loss in output of $2.5 \%$ versus $2.25 \%$ ), but with a more robust expansion thereafter (about $12 \%$ more in cumulative terms over the subsequent expansion, with the expansion lasting about 4 years longer). There does not seem to be as marked an effect pre-WW2.

Tables 5 and 6 reveal an interesting juxtaposition: in the post-WW2 era, whereas rapid credit growth in the expansion is associated with a longer expansion, a deeper recession but an overall net gain, it is below average credit growth in the recession that results in more growth in the expansion even at a small cost of a deeper recession in the short-term. It is natural to ask then the extent to which high credit growth cycles follow each other. Is rapid growth in the expansion followed by a quick deceleration in the recession? Or 
Table 6: Duration and rate of real GDP cycles — stratified by credit growth in current recession

\begin{tabular}{|c|c|c|c|c|c|c|}
\hline & \multicolumn{3}{|c|}{ Current Recession } & \multicolumn{3}{|c|}{ Subsequent Expansion } \\
\hline & Full Sample & Pre-WW2 & Post-WW2 & Full Sample & Pre-WW2 & Post-WW2 \\
\hline \multicolumn{7}{|c|}{ Duration (years) } \\
\hline $\begin{array}{c}\text { High Credit } \\
\text { Recession }\end{array}$ & $\begin{array}{l}1.5 \\
(0.9)\end{array}$ & $\begin{array}{l}1.5 \\
(0.9)\end{array}$ & $\begin{array}{l}1.3 \\
(.5)\end{array}$ & $\begin{array}{c}3 \cdot 9 \\
(3 \cdot 7)\end{array}$ & $\begin{array}{c}2.8 \\
(2.3)\end{array}$ & $\begin{array}{c}6.4 \\
(4.9)\end{array}$ \\
\hline $\begin{array}{l}\text { Low Credit } \\
\text { Recession }\end{array}$ & $\begin{array}{l}1.6 \\
(0.9)\end{array}$ & $\begin{array}{l}1.7 \\
(1.0)\end{array}$ & $\begin{array}{l}1.6 \\
(0.9)\end{array}$ & $\begin{array}{c}6.1 \\
(6.4)\end{array}$ & $\begin{array}{c}3.2 \\
(2.9)\end{array}$ & $\begin{array}{l}10.2 \\
(8.2)\end{array}$ \\
\hline \multicolumn{7}{|l|}{ Rate (\% p.a.) } \\
\hline $\begin{array}{c}\text { High Credit } \\
\text { Recession }\end{array}$ & $\begin{array}{l}-3.2 \\
(3.0)\end{array}$ & $\begin{array}{l}-4.0 \\
(3 \cdot 3)\end{array}$ & $\begin{array}{l}-1.9 \\
(1.7)\end{array}$ & $\begin{array}{c}4 \\
(2.5)\end{array}$ & $\begin{array}{c}4.8 \\
(2.8)\end{array}$ & $\begin{array}{c}2.7 \\
(1.3)\end{array}$ \\
\hline $\begin{array}{l}\text { Low Credit } \\
\text { Recession }\end{array}$ & $\begin{array}{l}-1.9 \\
(1.7)\end{array}$ & $\begin{array}{l}-2.3 \\
(2.1)\end{array}$ & $\begin{array}{l}-1.4 \\
(1.2)\end{array}$ & $\begin{array}{c}3 \cdot 4 \\
(2.1)\end{array}$ & $\begin{array}{c}3.8 \\
(2.4)\end{array}$ & $\begin{array}{c}2.9 \\
(1.4)\end{array}$ \\
\hline Observations & 287 & 173 & 114 & 269 & 165 & 104 \\
\hline
\end{tabular}

Notes: Duration refers to the number of periods that each phase between turning points lasts. Rate refers to the annual rate of change between turning points. High/Low Credit refers to whether credit growth during the recession is above/below country specific means. Expansions sorted by behavior of credit (above/below country-specific mean) in the preceding recession. Standard errors in parenthesis. See text.

is there no relation? To answer these questions, one can calculate the state-transition probability matrix relating each type of cycle binned by above or below credit growth. This transition probability matrix is reported in Table A.1 in the appendix.

Table A.r suggests that knowing whether the state of the preceding expansion was in the High Credit or Low Credit bins has little predictive power about the state in the current recession or the expansion that follows (the transition probabilities across all possible states are almost all 0.5). The type of recession also appears to have little influence on the type of expansion the economy is likely to experience. However, in the post-WW2 era we do find that a Low Credit recession is slightly more likely $(p=0.62)$ to be followed by a Low Credit expansion. This contrasts with the pre-WW2 sample where a Low Credit recession seem to affect only the likelihood $(p=0.71)$ that the following recession would also be Low Credit. By and large, it is safe to say that the type of recession or expansion experienced seems to have very little influence on future cyclical activity. 


\section{Credit and the Real Economy: A Historical and International Perspective}

This section follows in the footsteps of the real business cycle literature. First we reexamine core stylized facts about aggregate fluctuations using our richer dataset. Second, we study the correlation between real and financial variables, as well the evolution of these correlations over time in greater detail. The overarching question is whether the increase in the size of the financial sector discussed in previous sections left its mark on the relation between real and financial variables over the business cycle.

We structure the discussion around three key insights. First, we confirm that the volatility of real variables has declined over time, specially since the mid-1980s. The origins of this so called Great Moderation, first discovered by McConnell and PérezQuirós (2000), are still a matter of lively debate. Institutional labor-market mechanisms, such as a combination of de-unionization and skill-biased technological change, are a favorite of Acemoglu, Aghion, and Violante (2001). Loss of bargaining power by workers is a plausible explanation for what happened in the U.S. and in the U.K. yet the Great Moderation transcended these Anglo-Saxon economies, and was felt in nearly every advanced economy in our sample (cf. Stock and Watson 2005). As a result, alternative explanations have naturally gravitated toward phenomena with wider reach. Among them, some have argued for the "better policy" explanation, such as Boivin and Giannoni (2006). For others, the evolving role of commodity prices in more service-oriented economies along with more stable markets are an important factor, such as for Nakov and Pescatori (2010). Of course, sheer-dumb-luck, a sequence of positive shocks more precisely, is Ahmed, Levin, and Wilson's (2004) explanation. The debate rages on. And yet, despite the moderation of real fluctuations, the volatility of asset prices has increased over the 2oth century.

Second, the correlation of output, consumption, and investment growth with credit has 
grown substantially over time and with a great deal of variation in the timing depending on the economy considered. Credit, not money, is much more closely associated with changes in GDP, investment, and consumption today than it was in earlier, less-leveraged eras of modern economic development. Third, the correlation between price level changes (inflation) and credit has also increased substantially and has become as close as the nexus between monetary aggregates and inflation. This too marks a change with earlier times when money, not credit, exhibited the closest correlation with inflation.

We start by reporting standard deviations (volatility) and autocorrelations of variables with their first lag (persistence) of real aggregates (output, consumption, investment, current account as a ratio to GDP) as well as those of price levels and real asset prices. In keeping with standard practice in this literature, all variables have been detrended using the Hodrick-Prescott filter, which removes low-frequency movements from the data. ${ }^{3}$

Finally, we follow general practice and report results for the full sample, 1870-2013, and also present the results over the following subsamples: the gold standard era (18701913); the interwar period (1919-1938); the Bretton-Woods period (1948-1971); and the era of fiat money and floating exchange rates (1972-2013). We exclude WW1 and WW2. This split of the sample by time period corresponds only loosely to the rise of leverage on a country-by-country basis. The next section of the paper directly conditions the business cycle moments on credit-to-GDP levels for a more precise match on this dimension.

\section{A. Volatility and Persistence of the Business Cycle}

Two basic features of the data are reported in Table 7: volatility (generally measured by the standard deviation of the log of HP-detrended annual data) and persistence (measured with the first order serial correlation parameter). In line with previous studies, our data show that output volatility peaked in the interwar period, driven by the devastating

\footnotetext{
3 Using $\lambda=100$ for annual data. For a more detailed discussion of the different detrending methods such as the Baxter-King bandpass filter and their impact on macroeconomic aggregates see the discussion in Basu and Taylor (1999) as well as Canova (1998).
} 
Table 7: Properties of macroeconomic aggregates and asset prices - moments of detrended variables

\begin{tabular}{lcccc}
\hline \hline & \multicolumn{3}{c}{ Subsample } \\
\cline { 2 - 4 } & Gold Standard & Interwar & Bretton Woods & Float \\
\hline Volatility (s.d.) & & & \\
log real output p.c. & 0.03 & 0.06 & 0.03 & 0.02 \\
$\log$ real consumption p.c. & 0.04 & 0.06 & 0.03 & 0.02 \\
$\log$ real investment p.c. & 0.12 & 0.25 & 0.08 & 0.08 \\
Current account / GDP & 1.83 & 2.57 & 1.70 & 1.67 \\
$\log$ CPI & 0.09 & 1.11 & 0.09 & 0.03 \\
$\log$ real share prices & 0.13 & 0.22 & 0.20 & 0.25 \\
$\log$ real house prices & 0.09 & 0.14 & 0.09 & 0.09 \\
\hline Persistence (autocorrelation) & & & & \\
$\log$ real output p.c. & & & 0.79 & 0.65 \\
$\log$ real consumption p.c. & 0.49 & 0.63 & 0.73 & 0.71 \\
$\log$ real investment p.c. & 0.35 & 0.55 & 0.57 & 0.66 \\
Current account / GDP & 0.47 & 0.57 & 0.21 & 0.43 \\
$\log$ CPI & 0.30 & 0.20 & 0.90 & 0.80 \\
$\log$ real share prices & 0.83 & 0.58 & 0.63 & 0.57 \\
$\log$ real house prices & 0.42 & 0.61 & 0.60 & 0.75 \\
\hline \hline
\end{tabular}

Notes: Variables detrended using the HP filter with $\lambda=100$. Volatility refers to the S.D. of the detrended series; Persistence refers to first order serial correlation in the detrended series. All variables in logs and in per capita except for the current account to GDP ratio. Output, consumption and investment reported in real terms, per capita (p.c.), deflated by the CPI. Share prices and house prices deflated by the CPI. See text.

collapse of output during the Great Depression. The Bretton-Woods and free floating eras generally exhibited lower output volatility than the gold standard period. The standard deviation of log output was about 50\% higher in the pre-WW2 period than after the war. The idea of declining macroeconomic fluctuations is further strengthened by the behavior of consumption and investment. Relative to gold standard times, the standard deviation of investment and consumption was 50\% lower in the post-WW2 years.

At the same time, persistence has also increased significantly. In the course of the 2oth century, business cycles have generally become shallower and longer, as reported earlier. A similar picture emerges with respect to price level fluctuations. In terms of price level stability, it is noteworthy that the free floating era stands out from the periods of fixed exchange rates with respect to the volatility of the price level. The interwar period also 
Table 8: Properties of national expenditure components - moments of differenced variables

\begin{tabular}{|c|c|c|c|c|c|c|c|c|}
\hline & \multicolumn{2}{|c|}{ Full sample } & \multicolumn{2}{|c|}{ Pre-WW2 } & \multicolumn{2}{|c|}{ Post-WW2 } & \multicolumn{2}{|c|}{ Float } \\
\hline & U.S. & Pooled & U.S. & Pooled & U.S. & Pooled & U.S. & Pooled \\
\hline \multicolumn{9}{|c|}{ Standard Deviations Relative to Output } \\
\hline $\operatorname{sd}(c) / \operatorname{sd}(y)$ & 0.77 & 1.05 & 0.77 & 1.09 & 0.72 & 1.01 & 0.94 & 1.02 \\
\hline $\operatorname{sd}(i) / \operatorname{sd}(y)$ & 5.20 & $3 \cdot 41$ & $5 \cdot 54$ & $3 \cdot 70$ & 2.86 & 2.82 & 2.68 & 3.22 \\
\hline $\operatorname{sd}(g) / \operatorname{sd}(y)$ & 2.74 & 2.77 & 2.32 & 2.94 & 4.27 & 2.35 & 1.67 & 1.73 \\
\hline $\operatorname{sd}(n x) / \operatorname{sd}(y)$ & 0.62 & 1.73 & 0.70 & 2.01 & 0.54 & 1.41 & 0.60 & 1.37 \\
\hline \multicolumn{9}{|c|}{ Correlations with Output } \\
\hline $\operatorname{corr}(c, y)$ & 0.87 & 0.73 & 0.90 & 0.72 & 0.69 & 0.75 & 0.90 & 0.82 \\
\hline $\operatorname{corr}(i, y)$ & 0.70 & 0.59 & 0.77 & 0.59 & 0.20 & 0.59 & 0.82 & 0.82 \\
\hline $\operatorname{corr}(g, y)$ & -0.10 & 0.00 & -0.29 & -0.03 & 0.43 & 0.10 & -0.28 & -0.06 \\
\hline $\operatorname{corr}(n x, y)$ & -0.18 & -0.15 & -0.14 & -0.11 & -0.34 & -0.24 & -0.62 & -0.33 \\
\hline
\end{tabular}

Notes: Variables detrended using the HP filter with $\lambda=100$. Raw variables are log real per capita quantities, except net export share $(n x=\mathrm{NX} / \mathrm{GDP})$. Standard deviations reported as a ratio to the standard deviation of detrended output. Correlation with output is simple correlation coefficient with detrended output. Full sample: 1870-2013; Pre-WW2: 1870-1938; Post-WW2: 1948-1971; Float: 1972-2013. See text.

stands out, but both relative to the gold standard era and the Bretton-Woods period, the past four decades have been marked by a much lower variance of prices.

Table 7 reveals a surprising insight: contrary to the Great Moderation, the standard deviation of real stock prices has increased. As we have seen before, both output and consumption have become less volatile over the same period. The divergence between the declining volatility in consumption and output on the one hand, and increasingly volatile asset prices on the other is also noteworthy as it seems to apply only to stock prices. The standard deviation of detrended real house prices has remained relatively stable over time. The interwar period stands out with respect to volatility of house prices, because real estate prices fluctuated strongly after $W_{1}$, particularly in Europe, and then again during the Great Depression, as discussed in Knoll, Schularick, and Steger (2015).

What about the behavior of different expenditure components over time? Table 8 shows that key empirical relationships established in the earlier literature are robust to our more comprehensive dataset. Consumption is about as volatile as output (in 
terms of relative standard deviations) although less so in the U.S. However, investment is consistently more volatile than output (more than twice as much). Table 8 also shows that these relationships hold for virtually all countries and across subperiods. There is some evidence that the relative volatility of investment and government spending is declining over time.

We also confirm that consumption and investment are procyclical with output. This comovement seems to increase over time, potentially reflecting better measurement. In contrast to consumption and investment, government expenditures exhibit much less of a systematic tendency to comove with output, suggesting perhaps a fiscal smoothing mechanism at work. Net export changes are also only weakly correlated with output movements.

Overall, with more and better data we confirm a number of key stylized facts from the literature. Output volatility has declined over time, consumption is less, and investment considerably more volatile than output, and both comove positively with output. Government spending and net exports generally fluctuate in a way less clearly correlated with output. Despite broad-based evidence of declining amplitudes of real fluctuations, the volatility of real asset prices has not declined-and, in the case of stock prices, actually increased in the second half of the 2oth century relative to the pre-WW2 period.

\section{B. Credit, Money, and the Business Cycle}

Evaluating the merits of alternative stabilization policies is one of the key objectives of macroeconomics. It is therefore natural to ask how have the cross-correlations of real and financial variables developed over time. In Table 9, we track the correlations of credit as well as money growth rates with output, consumption, investment, and asset price growth rates. Thus, looking now at first differences, the main goal is to determine if and how these correlations have changed over time, especially with the sharp rise of credit associated with the financial hockey stick. 
Table 9: Real money and credit growth: cross-correlations with real variables

\begin{tabular}{|c|c|c|c|c|c|c|c|c|}
\hline & \multicolumn{2}{|c|}{ Full sample } & \multicolumn{2}{|c|}{ Pre-WW2 } & \multicolumn{2}{|c|}{ Post-WW2 } & \multicolumn{2}{|c|}{ Float } \\
\hline & U.S. & Pooled & U.S. & Pooled & U.S. & Pooled & U.S. & Pooled \\
\hline \multicolumn{9}{|c|}{ Real money growth } \\
\hline$\Delta y$ & 0.36 & 0.20 & 0.47 & 0.12 & 0.24 & 0.33 & 0.22 & 0.29 \\
\hline$\Delta c$ & 0.33 & 0.20 & 0.35 & 0.08 & 0.50 & 0.36 & 0.47 & 0.32 \\
\hline$\Delta i$ & 0.17 & 0.11 & 0.25 & 0.06 & -0.02 & 0.21 & 0.07 & 0.24 \\
\hline$\Delta h p$ & 0.16 & 0.30 & 0.11 & 0.24 & 0.26 & 0.33 & 0.22 & 0.27 \\
\hline \multicolumn{9}{|c|}{ Real credit growth } \\
\hline$\Delta y$ & 0.40 & 0.21 & 0.30 & 0.04 & 0.67 & 0.53 & 0.76 & 0.46 \\
\hline$\Delta c$ & 0.34 & 0.25 & 0.21 & 0.11 & 0.68 & 0.52 & 0.80 & 0.48 \\
\hline$\Delta i$ & 0.15 & 0.20 & 0.10 & 0.10 & 0.52 & 0.42 & 0.63 & 0.46 \\
\hline$\Delta h p$ & -0.01 & 0.37 & -0.18 & 0.29 & 0.41 & 0.45 & 0.55 & 0.49 \\
\hline
\end{tabular}

Notes: All variables expressed in first differences of the log and in real per capita terms. Correlations between real money growth and real credit growth (measured with total bank lending to the non financial sector) with: the growth rate of output $(\Delta y)$; consumption $(\Delta c)$; investment $(\Delta i)$; and house prices $(\Delta h p)$. Full sample: 1870-2013; Pre-WW2: 1870-1938; Post-WW2: 1948-1971; Float: 1972-2013. See text.

These correlations have become larger. Table 9 shows that before WW2 the correlations of credit growth and output growth were positive but low. In the post-WW2 era, the correlations between credit and real variables have increased substantially, doubling from one period to the other. This pattern not only holds for credit and output. It is even more evident for investment and consumption, which were only loosely correlated with movements in credit before WW2. Unsurprisingly in light of the dominant role played by mortgage lending in the growth of leverage, the correlation between credit growth and house price growth has never been higher than in the past few decades.

The comparison with the cross-correlation of monetary aggregates with real variables shown in Table 9 echoes our previous research (Jordà, Schularick and Taylor 2015). In the age of credit, monetary aggregates come a distant second when it comes to the association with macroeconomic variables. Real changes in M2 were more closely associated with cyclical fluctuations in real variables than credit before WW2. This is no longer true in the postwar era. As Table 9 demonstrates, in recent times changes in real credit are generally much more tightly aligned with real fluctuations than those of money. 
Table 10: Nominal money and credit growth: cross-correlations with inflation

\begin{tabular}{|c|c|c|c|c|c|c|c|c|}
\hline \multirow[b]{2}{*}{ Country } & \multicolumn{4}{|c|}{ Broad money growth (M2 or similar) } & \multicolumn{4}{|c|}{ Private credit growth (bank loans) } \\
\hline & Full & Pre-WW2 & Post-WW2 & Float & Full & Pre-WW2 & Post-WW2 & Float \\
\hline AUS & 0.52 & 0.27 & 0.40 & 0.49 & 0.51 & 0.23 & 0.40 & 0.44 \\
\hline BEL & -0.07 & - & -0.07 & -0.07 & 0.41 & 0.39 & 0.32 & 0.49 \\
\hline CAN & 0.57 & 0.51 & 0.51 & 0.70 & 0.50 & 0.46 & 0.33 & 0.65 \\
\hline $\mathrm{CHE}$ & 0.35 & 0.33 & 0.13 & 0.10 & 0.29 & 0.30 & 0.20 & 0.22 \\
\hline DEU & 0.49 & 0.59 & 0.17 & 0.48 & 0.22 & 0.32 & 0.08 & 0.52 \\
\hline DNK & 0.42 & 0.33 & 0.39 & 0.38 & 0.43 & 0.35 & 0.39 & 0.47 \\
\hline ESP & 0.61 & 0.25 & 0.54 & 0.74 & 0.29 & -0.20 & 0.36 & 0.45 \\
\hline FIN & 0.34 & 0.20 & 0.41 & 0.66 & 0.41 & 0.36 & 0.40 & 0.52 \\
\hline FRA & 0.48 & 0.44 & 0.41 & 0.45 & 0.39 & 0.16 & 0.68 & 0.63 \\
\hline GBR & 0.61 & 0.46 & 0.38 & 0.44 & 0.58 & 0.45 & 0.38 & 0.49 \\
\hline ITA & 0.51 & 0.47 & 0.38 & 0.73 & 0.48 & 0.49 & 0.28 & 0.66 \\
\hline JPN & 0.43 & 0.01 & 0.58 & 0.61 & 0.54 & 0.47 & 0.72 & 0.53 \\
\hline NLD & 0.33 & 0.36 & 0.14 & 0.31 & 0.66 & 0.65 & 0.41 & 0.49 \\
\hline NOR & 0.57 & 0.43 & 0.49 & 0.60 & 0.60 & 0.61 & 0.33 & 0.48 \\
\hline PRT & 0.70 & 0.81 & 0.64 & 0.71 & 0.33 & 0.19 & 0.42 & 0.50 \\
\hline SWE & 0.53 & 0.60 & 0.26 & 0.29 & 0.65 & 0.66 & 0.44 & 0.56 \\
\hline USA & 0.53 & 0.61 & 0.21 & 0.27 & 0.51 & 0.67 & -0.02 & 0.25 \\
\hline Pooled & 0.51 & 0.43 & 0.46 & 0.55 & 0.43 & 0.34 & 0.44 & 0.54 \\
\hline
\end{tabular}

Notes: Correlations between broad money growth and private credit growth (measured with total bank lending to the non financial sector) with CPI inflation. Full sample: 1870-2013; Pre-WW2: 1870-1938; Post-WW2: 1948-1971; Float: 1972-2013. See text.

The growing importance of credit is also a key finding of this part of the analysis. In Table 10 we study the relationship between private credit, broad money, and price inflation. Are changes in the nominal quantity of broad money or changes in credit volumes more closely associated with inflation? Before WW2, broad money is generally more closely associated with inflation than credit. Moreover, the relationship between monetary factors and inflation appears relatively stable over time. Correlation coefficients are between 0.4 and 0.55 for all sub-periods.

The growing correlation between credit and inflation rates is noteworthy. In the preWW2 data, the correlation between loan growth and inflation was positive but relatively low. In the post-WW2 era, correlation coefficients rose and are of a similar magnitude to those of money and inflation. The mean correlation increased from 0.33 in the pre-WW2 
era to 0.54 in the free floating period. Clearly, both nominal aggregates exhibit a relatively tight relation with inflation, but here too the importance of credit appears to have been growing.

\section{Business Cycle Moments and Leverage}

We have emphasized two important points in previous sections. First, we invoked the financial hockey stick. Advanced economies over the last forty years have experienced an unprecedented shift in bank lending relative to GDP after a preceding century of near-stability. Second, the manner in which macroeconomic aggregates correlate with each other has evolved over time. Moreover, such correlations can vary considerably from one country to another within a given era.

In this section, following up on the latter point, we focus our argument on a different set of goalposts, but with the same purpose in mind. We now show that the alternative approach of describing business cycle properties in terms of key moments has arguably missed a very important driving force in the aggregate economic dynamics by ignoring the role of credit.

In this respect, and to zoom in on key stylized facts in the results that follow, we now adopt a straightforward empirical approach to summarize the data, by looking at the correlation (or, graphically, a scatter) of any given macroeconomic statistical moment of interest $(\hat{m})$ with the credit-to-GDP ratio $(\bar{x})$. Formally, we take the panel data for all countries $i$ and all years $t$, construct rolling 10-year windows of data $y_{i t}$ over the entire sample within which we compute a country-window specific moment $\hat{m}\left(y_{i t}\right)$ which we seek to relate to the average credit-to-GDP ratio $\bar{x}_{i t}$. Finally, we present the data and correlations using a binscatter diagram. In all such diagrams that follow, the points displayed are summary data for each moment computed when the credit-to-GDP ratio is grouped into 20 bins. The full sample regression line is then also plotted. Country fixed effects and a global real GDP per capita control are also included. 


\section{A. Central Moments are Correlated with Leverage}

To start with some of the most widely employed business cycle moments, Figure 7 presents the mean, s.d., skewness and, 1oth percentile of the annual growth rate of real GDP per capita, real consumption per capita, and real investment per capita (in 10-year rolling windows) using binscatters plotted against the (average in-window) credit/GDP ratio for our full historical sample. Figure 8 reports the exact same binscatters, for the exact same moments, but restricting attention to the post-WW2 sample. As a complement and robustness check, we report pooled binscatters without country fixed effects or the global real GDP per capita control in the appendix, and those results include variation across both time and space.

With four moments of three variables, the figure consists of twelve panels. It is immediately apparent that the assumption of stable parameters is widely rejected by the data. Nonzero slopes are clearly evident, and these slopes are statistically significantly different from zero. Moreover, in some cases the binscatter displays possible nonlinearities (e.g., the binscatter for the mean of real GDP growth in the first row, column (a) in Figure 7). We now discuss the results in more detail.

In Figure 7, column (a), we see first in row 1 that mean real GDP per capita growth is virtually uncorrelated with credit/GDP, but the mean does appear hump shaped, with lower mean growth at very low levels of credit/GDP and also at very high levels. This observation is consistent with an emerging notion: there can be "too much finance." This literature, which argues that the link between the size of the financial sector and economic growth may not be linear or monotonic (King and Levine 1993), with small or even negative impacts possible when an economy is highly leveraged (Philippon and Reshef 2013; Ceccheti and Kharroubi 2015; Arcand, Berkes, and Panizza 2015).

In row 2 we see that the s.d. of real GDP growth is declining in credit/GDP, suggesting a great moderation effect of sorts, whereby volatility has fallen as advanced economies 
Figure 7: Central Moments: binscatters against credit/GDP ratio for mean, s.d., skewness, and 1oth percentile of annual growth rate of real GDP per capita, real consumption per capita, real investment per capita, full sample 1870-2013, controlling for country fixed effects and global growth rate

(a) GDP
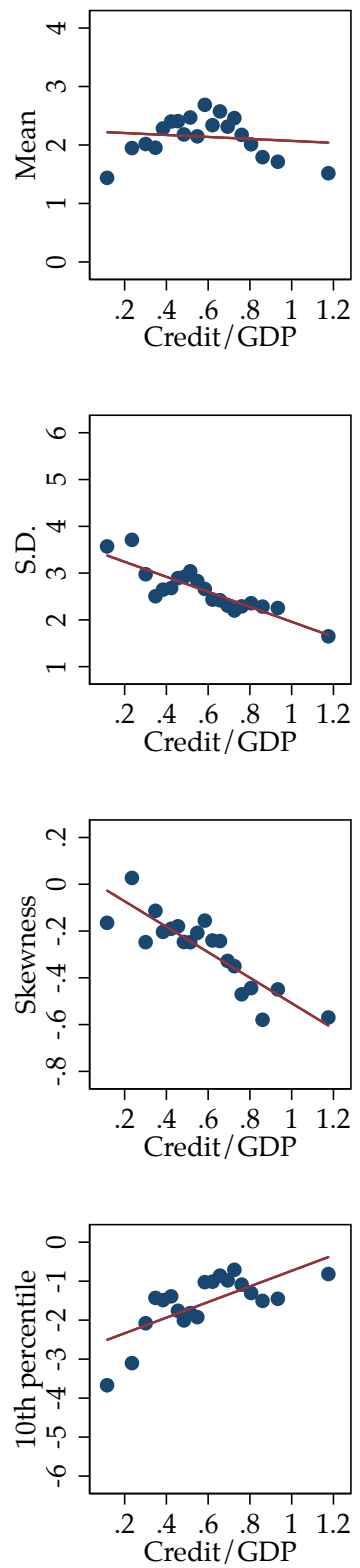

(b) Consumption
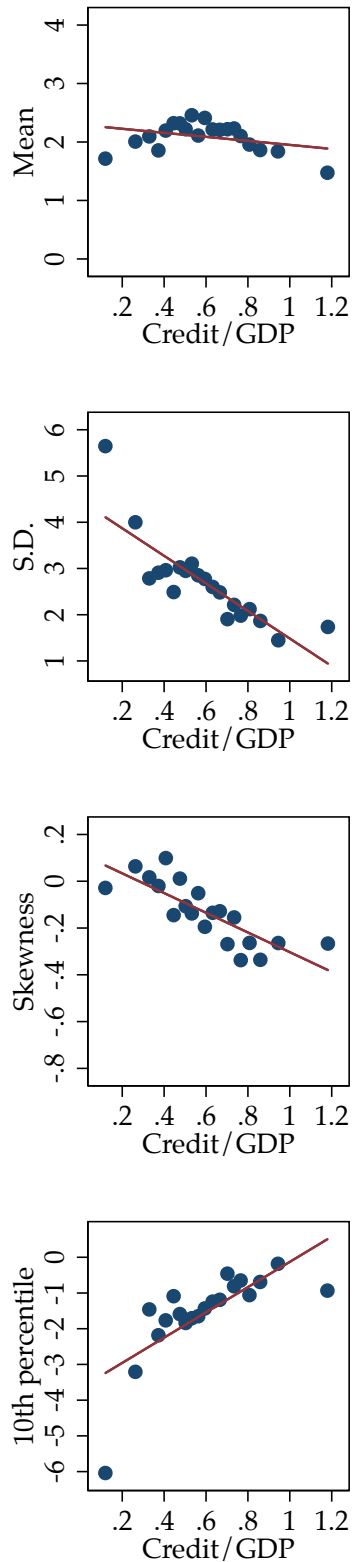

(c) Investment
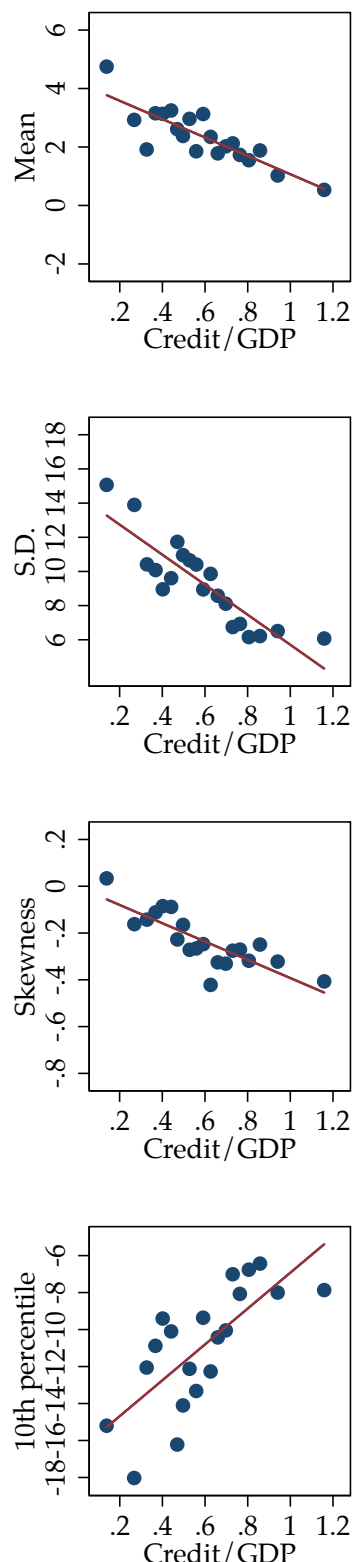

Notes: Binscatters based on 20 bins using 10-year rolling windows to calculate moments. Fitted line obtained using the full sample. See text. 
have leveraged up. However, in row 3 we see that the third moment reveals a more subtle angle to this story. Although the right tail of growth appears to become subdued as credit/GDP rises, the left tail does not, as indicated by rising skewness of growth outcomes. This rising skew fits with our earlier empirical work, in this and other papers, and the work of others, showing that leveraged economies are more at risk of steeper downturns and slower recoveries, often times these taking the form of financial crisis recessions (Reinhart and Rogoff 2009, 2013; Schularick and Taylor 2012; Jordà, Schularick, and Taylor 2013). From a theoretical standpoint, this result argues for macroeconomic models with an allowance for banking or financial sectors whose scale can influence the shape of recession outcomes. Even so, row 4 data on the lowest decile also suggest that lower-tail outcomes are somewhat better under higher credit/GDP, so the volatility effect dominates to mitigate the "rare disasters" as credit/GDP rises in this full sample setup.

To summarize, we have shown that the key moments of real GDP per capita growth are far from stable parameters, and historically they have varied with leverage. These results were obtained exploiting the full sample, but the patterns in the post-WW2 sample, the era of the financial hockey stick, may be even more interesting. In Figure 8 we therefore repeat the analysis using only post-1950 data.

The post-WW2 data tell an even more striking story. As before, more credit is associated with less volatility in growth, consumption and investment, but the decline in mean growth is much sharper. In the postwar data we are on the right side of the hump in growth rates. Output skew also becomes more extremely correlated with credit/GDP in the negative sense, even if the consumption and output correlations change less. Adding up all the effects, the row 4 results on shifts in the lowest decile now indicate that lowertail outcomes are worse under higher credit/GDP, so the worse mean and skew effects dominate to worsen the "rare disasters" as credit/GDP rises in the post-WW2 data.

To present some simple summary data, in Table 11 we stratify the sample into high and low bins, using the mean credit to GDP ratio as the threshold. We then calculate 
Figure 8: Central Moments: binscatters against credit/GDP ratio for mean, s.d., skewness, and 1oth percentile of annual growth rate of real GDP per capita, real consumption per capita, real investment per capita, post-WW2 sample 1950-2013, controlling for country fixed effects and global growth rate

(a) GDP
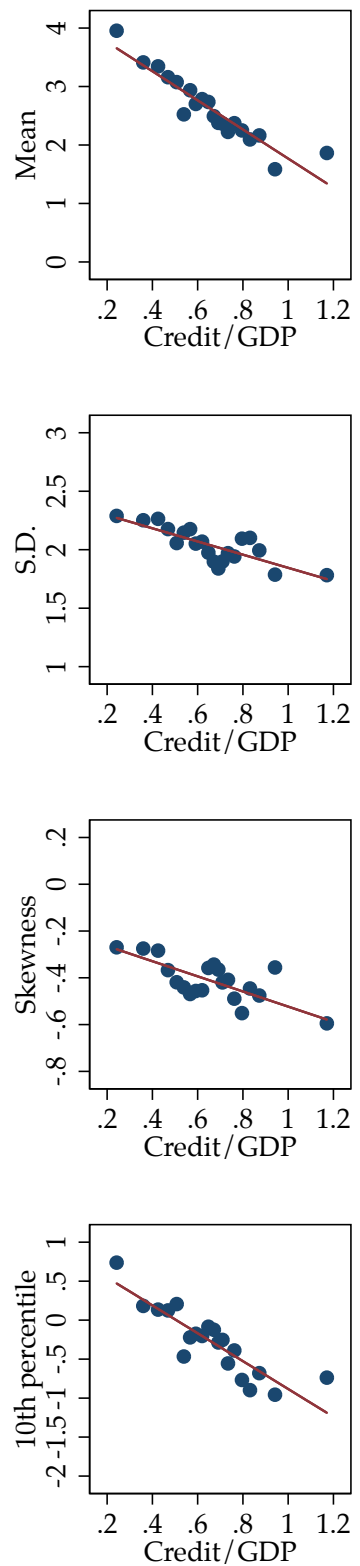

(b) Consumption
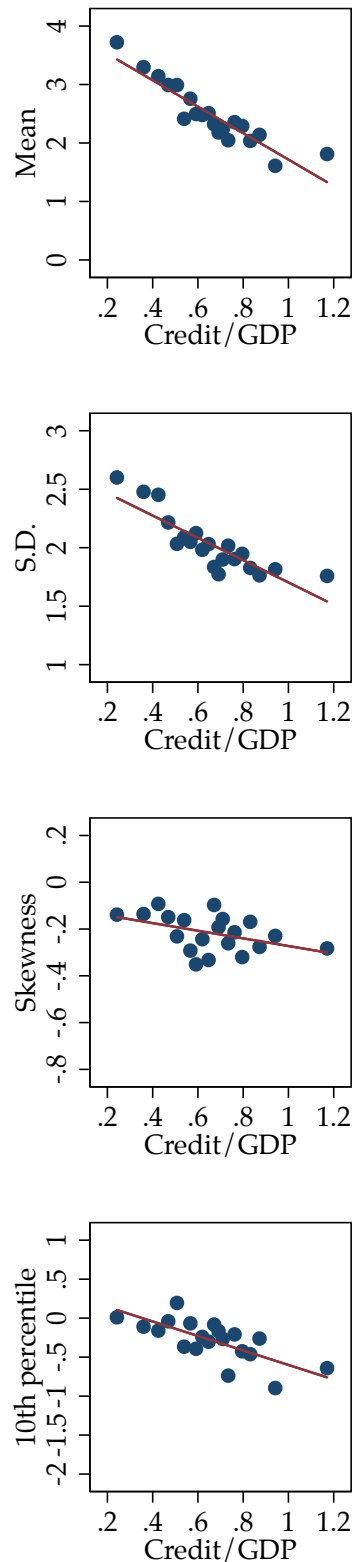

(c) Investment
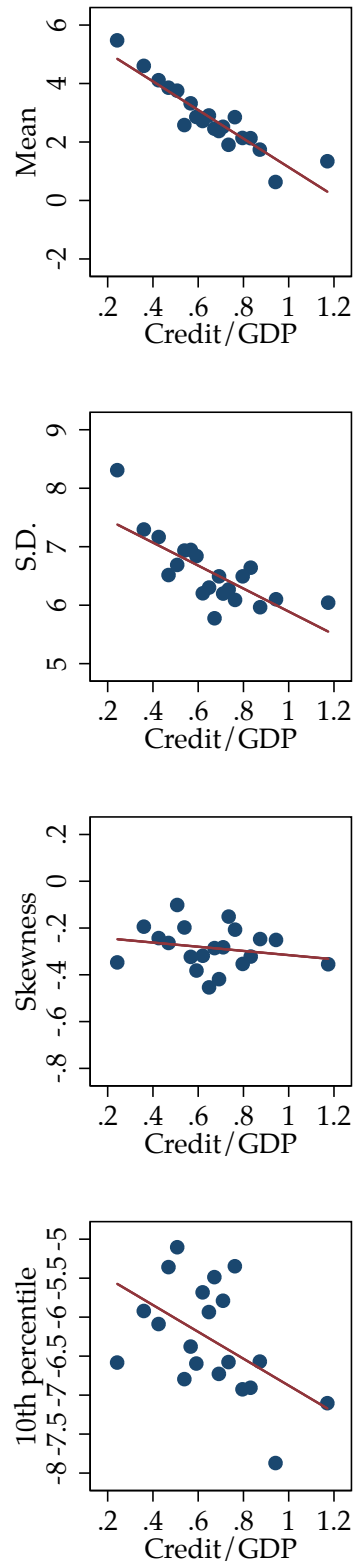

Notes: Binscatters based on 20 bins using 10-year rolling windows to calculate moments. Fitted line obtained using the full sample. See text. 
Table 11: Business cycle moments. Summary table for mean, s.d., skewness, and 1oth percentile at high/low levels of credit/GDP

\begin{tabular}{|c|c|c|c|c|c|c|}
\hline & \multicolumn{2}{|c|}{$\begin{array}{c}\text { Real GDP } \\
\text { growth per capita }\end{array}$} & \multicolumn{2}{|c|}{$\begin{array}{l}\text { Real consumption } \\
\text { growth per capita }\end{array}$} & \multicolumn{2}{|c|}{$\begin{array}{l}\text { Real investment } \\
\text { growth per capita }\end{array}$} \\
\hline & $\begin{array}{l}\text { High } \\
\text { credit }\end{array}$ & $\begin{array}{l}\text { Low } \\
\text { credit }\end{array}$ & $\begin{array}{l}\text { High } \\
\text { credit }\end{array}$ & $\begin{array}{l}\text { Low } \\
\text { credit }\end{array}$ & $\begin{array}{l}\text { High } \\
\text { credit }\end{array}$ & $\begin{array}{l}\text { Low } \\
\text { credit }\end{array}$ \\
\hline \multicolumn{7}{|c|}{ Full sample, 1870-2013 } \\
\hline \multicolumn{7}{|l|}{ Mean } \\
\hline Pooled & 1.5 & 2.2 & 1.5 & 2.2 & 1.2 & 2.9 \\
\hline Fixed effects & 1.7 & 2.0 & 1.7 & 2.0 & 1.7 & 2.3 \\
\hline \multicolumn{7}{|c|}{ Standard deviation } \\
\hline Pooled & 2.9 & $3 \cdot 7$ & $3 \cdot 3$ & $3 \cdot 9$ & 10.4 & 13.9 \\
\hline Fixed effects & 2.6 & 3.2 & 3.1 & 3.6 & 9.8 & 12.9 \\
\hline \multicolumn{7}{|l|}{ Skewness } \\
\hline Pooled & -0.6 & -0.7 & -0.2 & -0.2 & -0.6 & -2.8 \\
\hline Fixed effects & -0.7 & -0.2 & -0.2 & 0.0 & -0.2 & -2.3 \\
\hline \multicolumn{7}{|l|}{ Ioth percentile } \\
\hline Pooled & -1.8 & -2.0 & -1.9 & -2.3 & -10.1 & -9.1 \\
\hline Fixed effects & -1.3 & -1.5 & -1.6 & -2.3 & -8.5 & -8.7 \\
\hline Observations & 945 & 976 & 913 & 896 & 911 & 900 \\
\hline \multicolumn{7}{|c|}{ Post-WW2 sample, 1950-2013 } \\
\hline \multicolumn{7}{|l|}{ Mean } \\
\hline Pooled & 1.5 & 3.2 & 1.4 & 3.1 & 1.0 & $3 \cdot 7$ \\
\hline Fixed effects & 2.2 & 2.6 & 2.0 & 2.6 & 2.3 & 2.6 \\
\hline \multicolumn{7}{|c|}{ Standard deviation } \\
\hline Pooled & 2.3 & 2.5 & 2.2 & 2.7 & $7 \cdot 5$ & $7 \cdot 0$ \\
\hline Fixed effects & 1.8 & 2.1 & 2.0 & 2.4 & 6.8 & 6.7 \\
\hline \multicolumn{7}{|l|}{ Skewness } \\
\hline Pooled & -0.8 & 0.2 & -0.3 & 0.4 & -0.5 & -0.1 \\
\hline Fixed effects & -0.8 & 0.1 & -0.4 & 0.0 & -0.6 & -0.3 \\
\hline \multicolumn{7}{|l|}{ 1oth percentile } \\
\hline Pooled & -1.2 & 0.3 & -1.0 & -0.2 & -8.4 & -4.6 \\
\hline Fixed effects & 0.1 & 0.0 & -0.3 & -0.2 & -6.0 & $-5 \cdot 3$ \\
\hline Observations & 488 & 600 & 488 & 600 & 488 & 596 \\
\hline
\end{tabular}

Notes: Pooled refers to moments calculated with a pooled sample; Fixed effects refers to moments calculated with controls for country fixed effects and global growth rate; High/Low credit refers to whether the ratio of credit to GDP is above or below country specific means. See text. 
business cycle moments with and without country fixed effects. The table shows again that central business cycle moments change with leverage levels. But the full sample and post-WW2 results again reveal the dramatic shifts that took place in the era of the financial hockey stick. 4

The table thus reinforces the principal hypothesis of the paper: high credit is associated with less volatility in growth, consumption and investment. Equally consistently, we find that the mean drops, and skewness becomes more negative at high levels of debt. Credit may be associated with a dampening of the volatility of the cycle, but is also associated with more spectacular crashes, and worse tail events. In the post-WW2 period, the time of the financial hockey stick, these patterns grow more pronounced.

\section{B. Cross Moments are Correlated with Leverage}

Our next set of results explores whether high-frequency movements in the key macro variables cohere with movements in credit, and whether these are stable relationships over the wide span of historical experience. To summarize: yes, and no. Figure 9 presents the correlation of annual growth rate of real GDP per capita, real consumption per capita, and real investment per capita with the annual growth rate of real credit per capita using binscatters plotted against the credit/GDP ratio for our full historical sample.

Panel (a) shows that booms in real GDP per capita growth tend to be associated with booms in real credit per capita, since this correlation is positive in general. However, in low leverage economies this correlation is about 0.2 , rising to more than double or 0.5 in high leverage economies. So this reduced-form coherence of output and credit is much amplified in more leveraged economies, an intriguing result.

The same also holds true for both of the two key components of GDP, consumption and investment. Panel (b) shows that the correlation of real consumption per capita

\footnotetext{
4The bins in the table use the mean credit to GDP ratio as the threshold variable. Almost identical results are obtained if a smoothed variable, using the lagged 5-year moving average of the ratio, is employed instead, and are therefore not reported.
} 
Figure 9: Cross Moments: binscatters against credit/GDP ratio for correlation of annual growth rate of real credit per capita with real consumption per capita and real investment per capita, controlling for country fixed effects and global growth rate

(a) GDP-credit

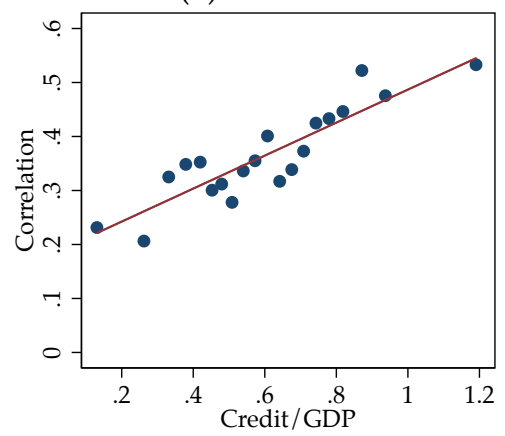

(b) Consumption-credit

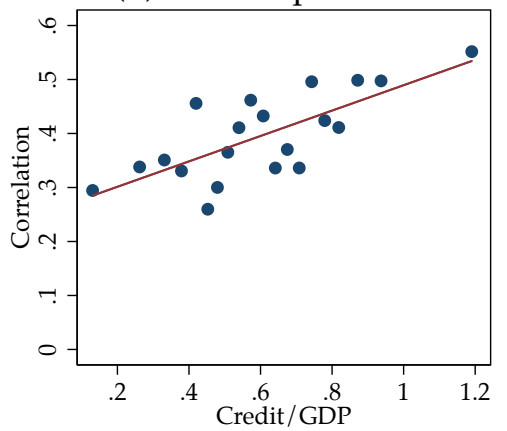

(c) Investment-credit

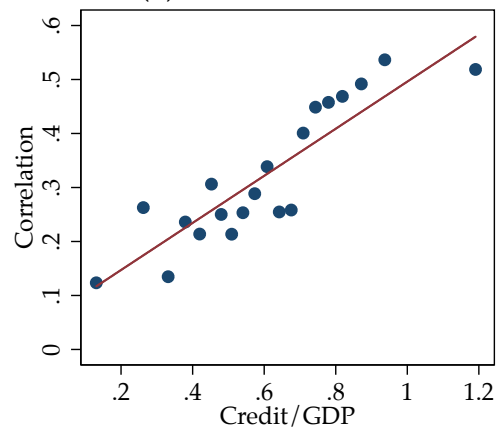

Notes: Binscatters based on 20 bins using 10-year rolling windows to calculate moments. Fitted line obtained using the full sample. See text.

growth and real credit per capita growth is positive and rising with the credit/GDP ratio. Panel (c) shows that the correlation of real investment per capita growth and real credit per capita growth is positive and rising with the credit/GDP ratio. These findings suggest that the new generation of macroeconomic models need to match macro fluctuations in such a way that both real consumption and real investment exhibit greater comovement with credit in more leveraged worlds.

Consistent with the above, our next analysis of cross moments asks if high frequency movements in consumption and investment are correlated with GDP. This is a very common business cycle moment which models have sought to match (e.g., Backus and Kehoe 1992; Backus, Kehoe, and Kydland 1992). But again, as one might expect given the prior results, these are not fixed parameters.

Figure 10 presents the correlation of annual growth rates of real consumption per capita and real investment per capita with annual growth rates of real GDP per capita, with binscatters plotted against the credit/GDP ratio for our full historical sample. Panel (a) shows that booms in real GDP per capita growth tend to be associated with booms in real consumption per capita, since this correlation is positive in general. However, in low 
Figure 10: Cross Moments: binscatters against credit/GDP ratio for correlation of annual growth rate of real consumption per capita, and real investment per capita with the annual growth rate of real GDP per capita, controlling for country fixed effects and global growth rate

(a) GDP-consumption

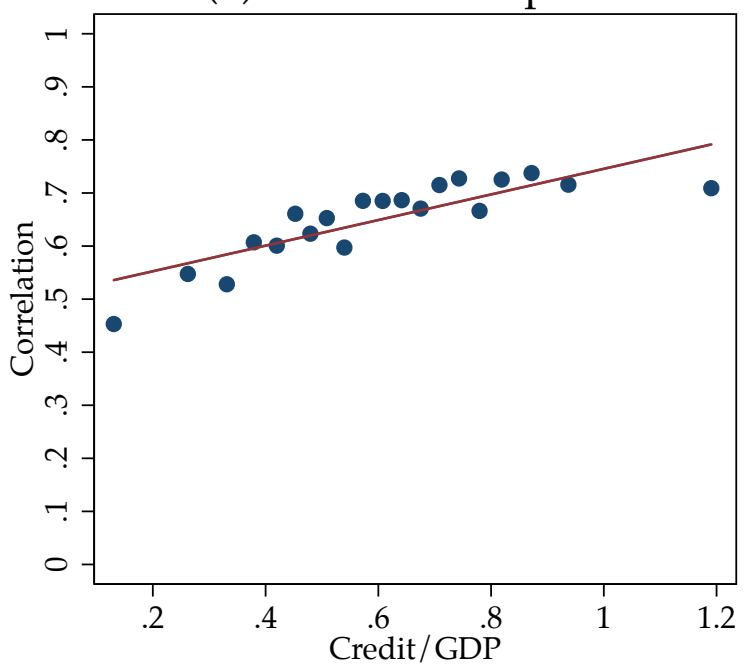

(b) GDP-investment

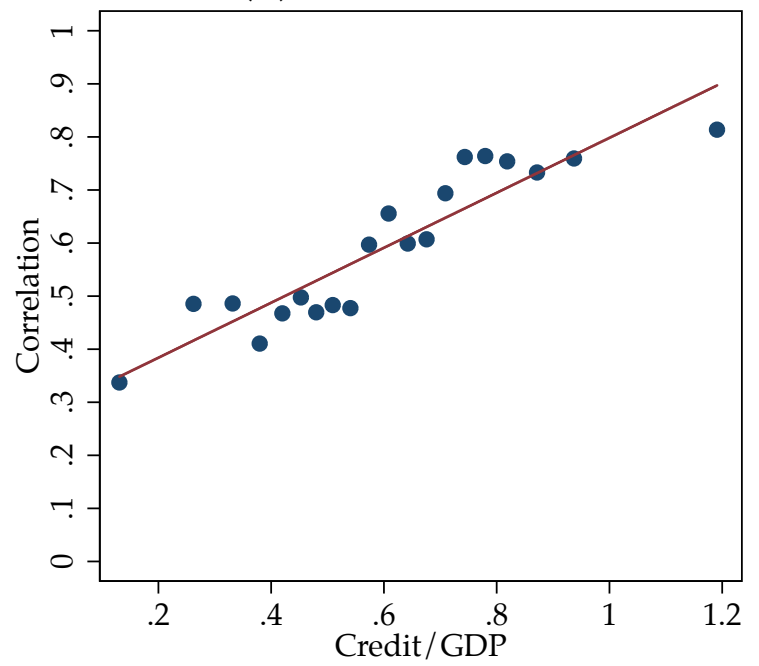

Notes: Binscatters based on 20 bins using 10-year rolling windows to calculate moments. Fitted line obtained using the full sample. See text.

leverage economies this correlation is about 0.4 , rising to 0.7 in high leverage economies. Panel (b) shows that booms in real GDP per capita growth tend to be associated with booms in real investment per capita, since this correlation is also positive. However, in low leverage economies this correlation is about 0.4 , rising to 0.8 in high leverage economies.

Maybe this is all not so terribly surprising, since we have already seen from the previous figure that all of the growth rates of these three aggregates-output, consumption, and investment-are more closely tied to the credit cycle as leverage rises; hence it is to be expected that they should also tend to become more closely tied to each other. Once again, this suggests that a key challenge for macroeconomic models is to develop a formulation whereby the coherence of the macroeconomic aggregates operates through a financial channel, and does so more strongly as the economy levers up. 


\section{International Moments are Correlated with Leverage}

Our final set of results turns to the moments of notable relevance for those interested in international business cycle models (e.g., Backus, Kehoe and Kydland 1999; Basu and Taylor 1999). Devotees of this subfield ponder what we can learn from movements in macro variables in multiple countries, either from looking at between-country correlations in aggregate outcomes, and/or by looking at the moments of key cross-border indicators like imports, exports, and the current account. We present three figures which give an overview of our findings in this area, and which again confirm how even at the international level, the key business cycle moments of interest in the literature have not been fixed, immutable parameters, but have shifted in tandem with the size of domestic financial systems.

Using the now familiar technique of binscatters employed above, Figure 11 presents three kinds of moments: volatility ratios of local annual growth rates of real consumption per capita relative to real GDP per capita, local annual growth rates of real consumption per capita relative to "world" (i.e., year sample mean) growth of real GDP per capita, and also the volatility of "world" real GDP per capita, with each of these moments plotted against the credit/GDP ratio for our full historical sample. The volatility ratio of local annual growth rates of real consumption per capita relative to real GDP per capita are fairly stable, and do not seem to depend much on leverage measured by credit/GDP; they may even be falling slightly, albeit the ratio exceeds 1 throughout the range, which indicates next to no international smoothing.

This result is consistent with Backus and Kehoe (1992) and Backus, Kehoe, and Kydland (1992). The volatility ratio of local annual growth rates of real consumption per capita relative to world real GDP per capita falls as credit/GDP rises; but the ratio again exceeds 1 throughout the range, which indicates limited risk sharing except in cases with large financial systems. The volatility of world real GDP per capita has not 
Figure 11: International Moments: binscatters against credit/GDP ratio for volatility ratios of local annual growth rates of real consumption per capita and real GDP per capita, local annual growth rates of real consumption per capita and world real GDP per capita, and volatility of world real GDP per capita, controlling for country fixed effects and global growth rate

(a) $\mathrm{SD}(\mathrm{c}) / \mathrm{SD}(\mathrm{y})$

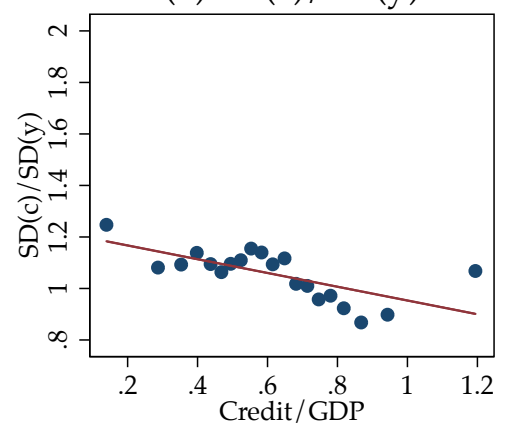

(b) $\operatorname{SD}(\mathrm{c}) / \mathrm{SD}(\mathrm{yW})$

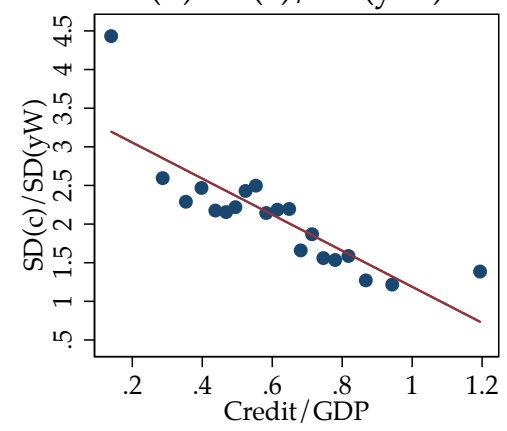

(c) $\mathrm{SD}(\mathrm{yW})$

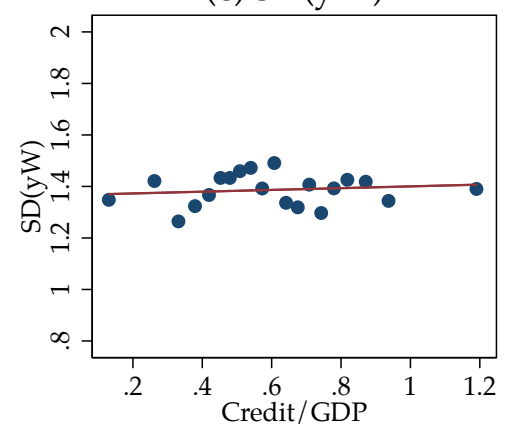

Notes: Binscatters based on 20 bins using 10-year rolling windows to calculate moments. Fitted line obtained using the full sample. $y$ refers to country specific output, $y W$ refers to global output (i.e., 17-country weighted mean). See text.

tended to fall as leverage rises. It may be asked how this is consistent with the earlier result that country level real GDP per capita growth saw its s.d. fall as leverage rose, but the answer lies in shifts in cross-country output correlations, as we shall see in a second. These findings suggest that international macro models may need to take into account the size of domestic financial systems when trying to replicate real world moments. In worlds with larger financial systems, smoothing and risk sharing may be enhanced, but at the global level, volatility may be increased, creating some potential tradeoffs (see, e.g., Caballero, Farhi, and Gourinchas 2008).

Figure 12 presents binscatters of four moments which capture the correlation of local and world cycles. From first to last these are, respectively, the correlation of local and "world" annual growth rates of real GDP per capita, real consumption per capita, real investment per capita, and real credit per capita, with each of these shown using binscatters plotted against the credit/GDP ratio for our full historical sample.

Panel (a) shows that the correlation of local and "world" annual growth rates of real GDP per capita is highly correlated with leverage measured by credit/GDP. Thus, 
Figure 12: International Moments: binscatters against credit/GDP ratio for correlation of local and world annual growth rates of real GDP per capita, real consumption per capita, real investment per capita, and real credit per capita, controlling for country fixed effects and global growth rate

(a) GDP, local-world

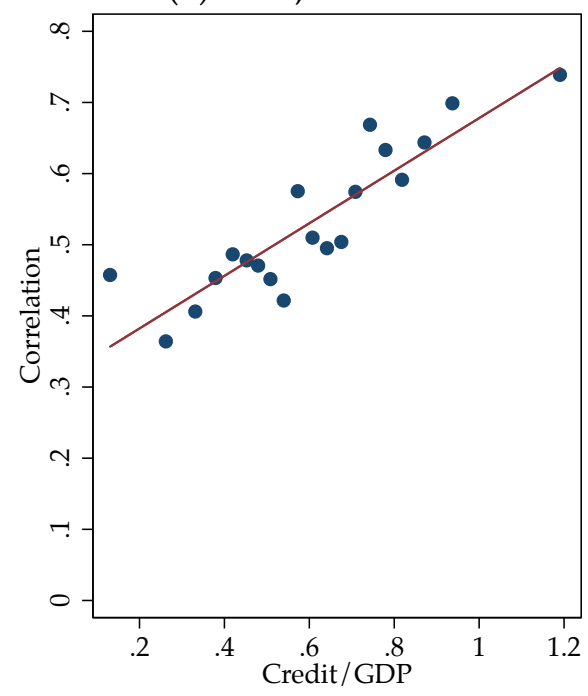

(c) Investment, local-world

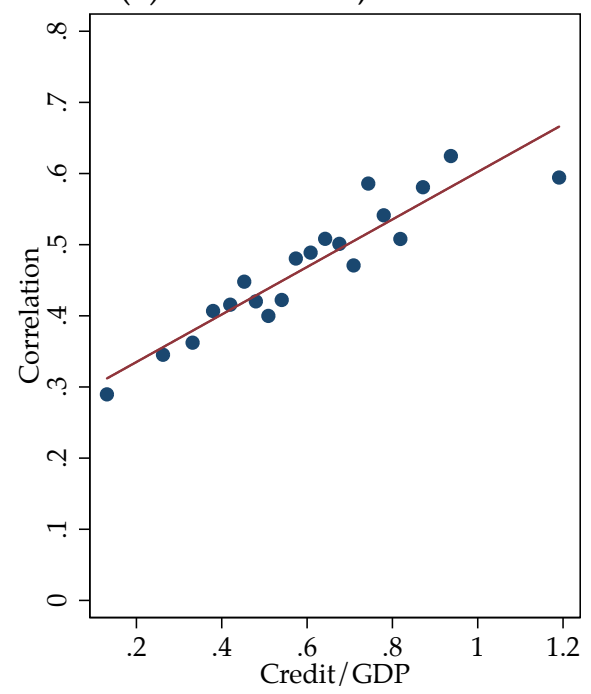

(b) Consumption, local-world

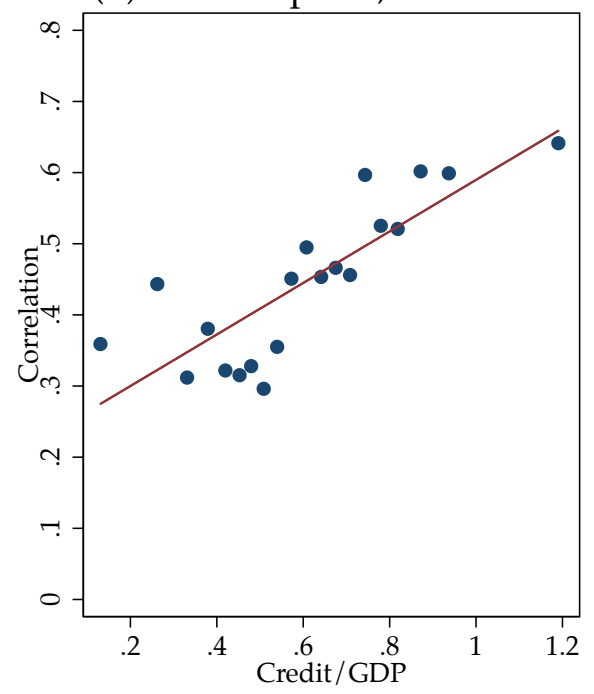

(d) Credit, local-world

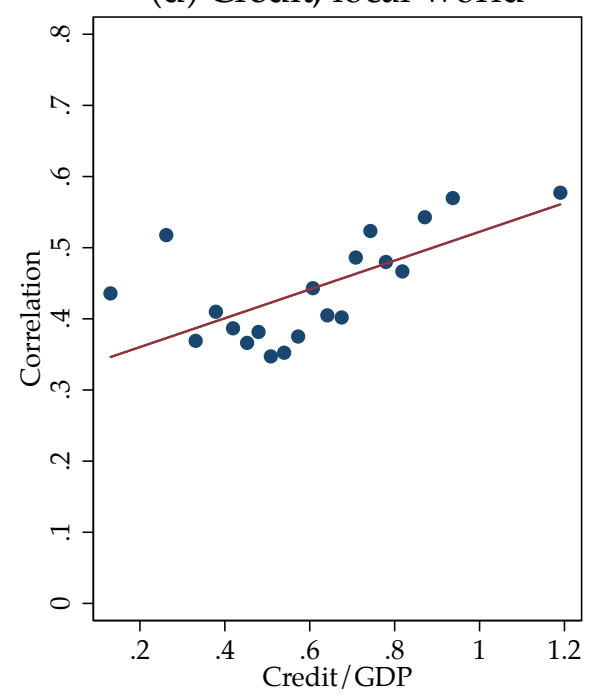

Notes: Binscatters based on 20 bins using 10-year rolling windows to calculate moments. Fitted line obtained using the full sample. See text. 
more leveraged economies have also tended to be economies with a local business cycle more tightly linked to the world cycle. Panel (b) shows that the correlation of local and "world" annual growth rates of real consumption per capita is also highly correlated with the leverage measure. This shows that the convergence of consumption growth to a common value, a risk sharing feature, seems to be associated with larger financial systems. However, the prior result suggest that ceteris is not paribus, in that those same highly leveraged economies also happen to have less risk sharing to do in the first place, having stronger output correlations. This then helps to explain why, in the previous figure, the consumption-output volatility ratio is relatively flat as leverage varies.

Finally, panels (c) and (d) show that the correlation of local and "world" annual growth rates of real investment per capita and real credit per capita are also highly correlated with the leverage measure. Country-level investment and credit boom-and-bust cycles tend to move more in sync with each other in a world with more leveraged economies. In total, this set of results points to the important role that domestic and, collectively, global financial systems might play in shaping business cycles at the local and world levels. Greater commonality of cycles is apparent in output, consumption, investment, and credit as financial systems lever up, and while this could reflect a purely coincidental increase in, say, real common shocks that "just-so-happened" to arise in those periods, it is also prima facie evidence that more leveraged economies may operate under very different model parameters with greater transmission of real and or financial shocks possible in worlds with more credit.

In our very last set of results, Figure 13 presents binscatters of for key moments of the three principal balance-of-payments variables, the annual change in the current account, exports, and imports, all measured relative to GDP, shown in panels (a), (b), and (c) lined up in columns. The first row of the figure shows the s.d., the second row the skewness, and the final row the correlation with annual growth rate of real GDP per capita.

The first row shows that the s.d. of the the annual change in CA/GDP is falling 
Figure 13: International Moments: binscatters against credit/GDP ratio for s.d. and skewness of d.CA/GDP, d.exports/GDP, and d.imports/GDP, and their correlation with annual growth rates of real GDP per capita, controlling for country fixed effects and global growth rate

(a) CA/GDP
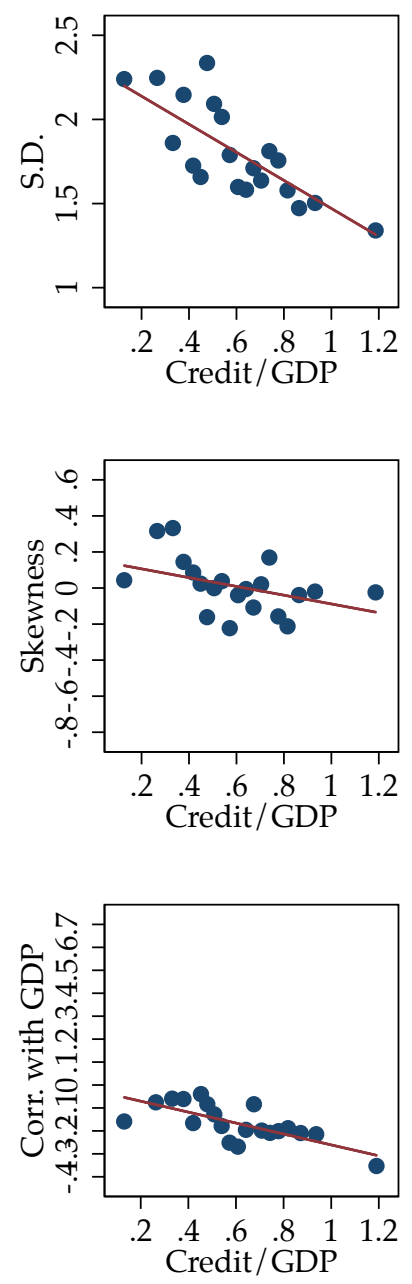

(b) Exports / GDP
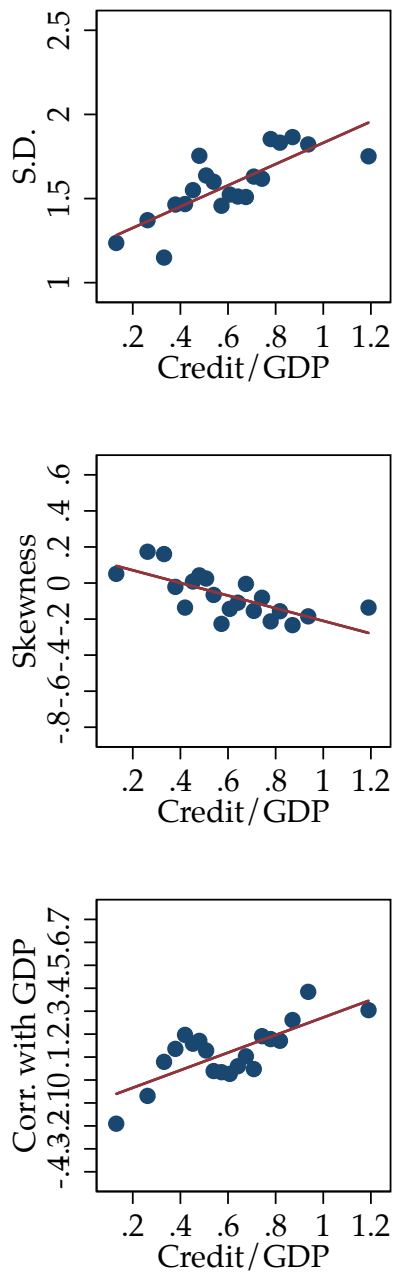

(c) Imports / GDP
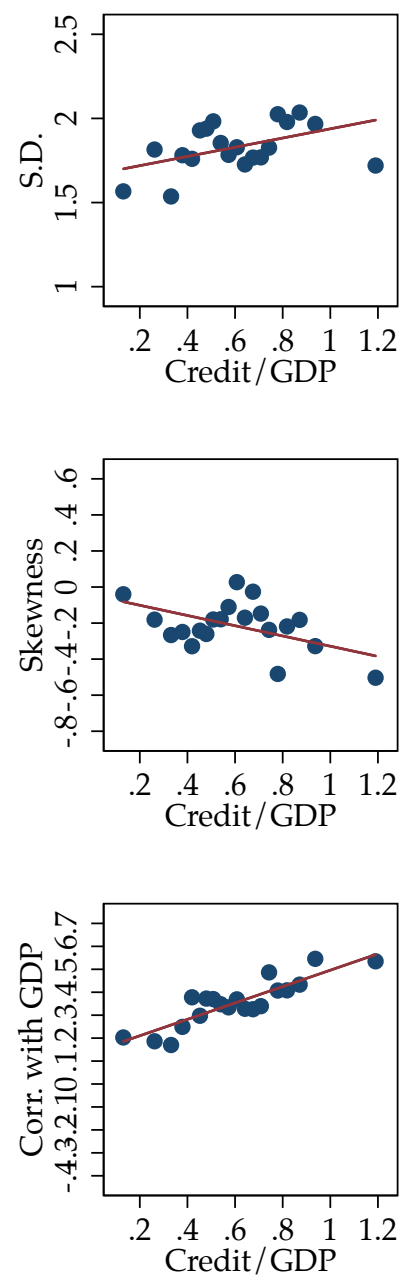

Notes: Binscatters based on 20 bins using 10-year rolling windows to calculate moments. Fitted line obtained using the full sample. See text. 
slightly with leverage, even though the s.d. of the the annual change in Exports/GDP and Imports/GDP are rising slightly with leverage. Thus it seems that increased volatility of gross balance of payments flows may be more associated with leverage than is the case for a net flow like the current account.

The second row shows that all of the third moments show an amplification in the negative direction with leverage, as skewness goes more negative for the annual change in CA/GDP, Exports/GDP and Imports/GDP. In the case of the net flow in the current account, these stylized facts suggests that models of reversals or "sudden stop" phenomena may reflect some financial channels whereby a sharper correction is more likely when the world is more leveraged. In the case of the gross flows measured by Exports/GDP and Imports/GDP, the results could be seen to be consistent with models where the cyclical influence of financial systems on trade flows can be particularly sharp during contractions of credit and trade flows.

The third row reveals subtle shifts in the cyclical correlations of the balance-ofpayments variables. The correlations of the annual change in CA/GDP, Exports/GDP, and Imports/GDP with real GDP per capita are typically amplified by more leverage as seen in other results. The change in CA/GDP is countercyclical (the correlation is negative) but this effect is more negative with high leverage. The change in Exports/GDP and Imports/GDP are both typically procyclical (the correlation is positive) but this effect is more positive with high leverage, and for these variables Imports/GDP shows greater procyclicality (rising from 0.2 to 0.6 ) than Exports/GDP (rising from o to 0.4 ) throughout the range. This suggests that local leverage levels may hold more powerful influence on the cyclicality of the import demand side than on the export supply side, lending prima facie support for theories that emphasize the impact of financial sector leverage on demand rather than supply channels. 


\section{Conclusion}

The advanced economies have become more financialized over the last 150 years, and dramatically so since the 1970s. Never in the history of the industrial world has leverage been higher, whether measured by private credit to the non-financial sector relative to income as we do in much of the paper, or relative to wealth as we do for a more select subsample of economies.

A stark fact of our recent past, the "financial hockey stick" is a key feature of history that is exposed by the new dataset we introduce in this paper. But beyond this, the new data can help expand the catalog of available business cycle facts to a much longer time frame, a wider range of countries, and a richer set of macroeconomic and financial variables. Derived from an arduous, multi-year collection effort, the data can help to further our progress towards a new, quantitative, macro-financial history of the advanced economies from which we can derive new business cycle facts. The new facts seen here have significant implications for macroeconomics, probably too many to discuss individually, with many more yet to be discovered by others interested in exploring our new data.

At a basic level, our core result — that higher leverage goes hand in hand with less volatility, but more severe tail events - is compatible with the idea that expanding private credit may be safe for small shocks, but dangerous for big shocks. Put differently, leverage may expose the system to bigger, rare-event crashes, but it may help smooth more routine, small disturbances. This meshes well with two recent lines of thinking about macrofinancial interactions.

Many models with financial frictions in the tradition of the canonical Bernanke, Gertler, and Gilchrist (1999) model share a mechanism by which small shocks to net worth are amplified through financial feedback loops. The amplification channels generated by these models typically operate through the corporate sector. However, such models based 
on corporate leverage have had mixed results when taken to the data (e.g., Kocherlakota 2000). We offer at least two explanations for this result. First, there is the observation that the great leveraging of the second half of the 2oth century took place primarily in the household and not the corporate sector. Second, it is only with a much longer sample that enough rare disasters can be recorded to analyze the data. Thus, we are led to wonder if the less well-known extension by Bernanke, Gertler, and Gilchrist (1999) with an application to the household balance sheet has been unduly neglected.

In other strands of the macro-finance literature, the household balance sheet is taking center stage. Although the literature continues to build on the venerable Kiyotaki and Moore (1997) model, increasing attention has shifted to households and mortgage borrowing. Iacoviello (2005) is perhaps the most influential theoretical paper in this tradition. On the empirical side, Mian and Sufi $(2013,2014)$ provide microeconomic evidence on the role of housing leverage in the recent financial crisis and the pace of the recovery from the Great Recession. Our data are entirely consistent with their findings and with the dynamics generated by Iacoviello's (2005) model.

Other researchers have focused less on who does the borrowing and more on how credit markets operate. Leverage makes the financial system less stable leading to increasing systemic risks as new macrofinancial models with strong non-linear responses to shocks show (e.g., Brunnermeier and Sannikov 2014). Adrian and Boyarchenko (2015) show that higher leverage generates higher consumption growth and lower consumption volatility in normal times at the cost of endogenous systemic financial risk. The predictions of these models are also consistent with evidence emerging from our new data.

Higher levels of debt may also trigger more pronounced deleveraging pressures in case of a sharp fall in asset prices or a tightening of borrowing limits. Following the logic laid out by Eggertsson and Krugman (2012) this may aggravate aggregate demand shortfalls - consistent with our observation of fatter left tails in high-debt regimes. Korinek and Simsek (2016) present a model where increasing household leverage gives 
rise to increasing aggregate demand externalities that may help explain the more severe recessions experienced in highly leveraged economies.

Along with financialization, we showed that advanced economies have become more synchronized, perhaps lessening the ability to hedge financial risk internationally. Moreover, economies have become more stable over time just as asset prices have become more volatile. In this regard, our results are in line with new research by Caballero, Fahri and Gourinchas (2008) and Caballero and Krishnamurthy (2009).

New data open new horizons for exploration. Just as in any modern science, our understanding of macroeconomics and finance evolves as new evidence is introduced, whether to refute old theories, or to unearth new facts. 


\section{A. Appendix}

Table A.1: Business cycle state transition probability matrices binned by credit

\begin{tabular}{|c|c|c|c|c|c|}
\hline & & \multicolumn{2}{|c|}{ Current expansion } & \multicolumn{2}{|c|}{ Current recession } \\
\hline & & High credit & Low credit & High credit & Low credit \\
\hline \multicolumn{6}{|l|}{ Full sample } \\
\hline \multirow{2}{*}{$\begin{array}{l}\text { Preceding } \\
\quad \text { expansion }\end{array}$} & High credit & 0.53 & 0.47 & 0.45 & 0.55 \\
\hline & Low credit & 0.53 & 0.47 & 0.44 & 0.56 \\
\hline \multirow{2}{*}{$\begin{array}{l}\text { Preceding } \\
\quad \text { recession }\end{array}$} & High credit & 0.52 & 0.48 & 0.50 & 0.50 \\
\hline & Low credit & 0.53 & 0.47 & 0.38 & 0.62 \\
\hline \multicolumn{6}{|l|}{ Pre-WW2 } \\
\hline \multirow{2}{*}{$\begin{array}{l}\text { Preceding } \\
\quad \text { expansion }\end{array}$} & High credit & 0.55 & 0.45 & 0.44 & 0.56 \\
\hline & Low credit & 0.52 & 0.48 & 0.35 & 0.65 \\
\hline \multirow{2}{*}{$\begin{array}{l}\text { Preceding } \\
\quad \text { recession }\end{array}$} & High credit & 0.54 & 0.46 & 0.50 & 0.50 \\
\hline & Low credit & 0.54 & 0.46 & 0.29 & 0.71 \\
\hline \multicolumn{6}{|l|}{ Post-WW2 } \\
\hline \multirow{2}{*}{$\begin{array}{l}\text { Preceding } \\
\quad \text { expansion }\end{array}$} & High credit & 0.49 & 0.51 & 0.51 & 0.49 \\
\hline & Low credit & 0.45 & 0.55 & 0.47 & 0.53 \\
\hline \multirow{2}{*}{$\begin{array}{l}\text { Preceding } \\
\quad \text { recession }\end{array}$} & High credit & 0.46 & 0.54 & 0.40 & 0.60 \\
\hline & Low credit & 0.38 & 0.62 & 0.52 & 0.48 \\
\hline
\end{tabular}

Notes: State transition probabilities are empirical probabilities that a given state will be followed by another state. High/Low Credit refers to whether credit growth during the expansion or recession is above/below country specific means. See text. 
Figure A.1: Central Moments: binscatters against credit/GDP ratio for mean, s.d., skewness, and 1oth percentile of annual growth rate of real GDP per capita, real consumption per capita, real investment per capita, full sample 1870-2013, no fixed effects

(a) GDP
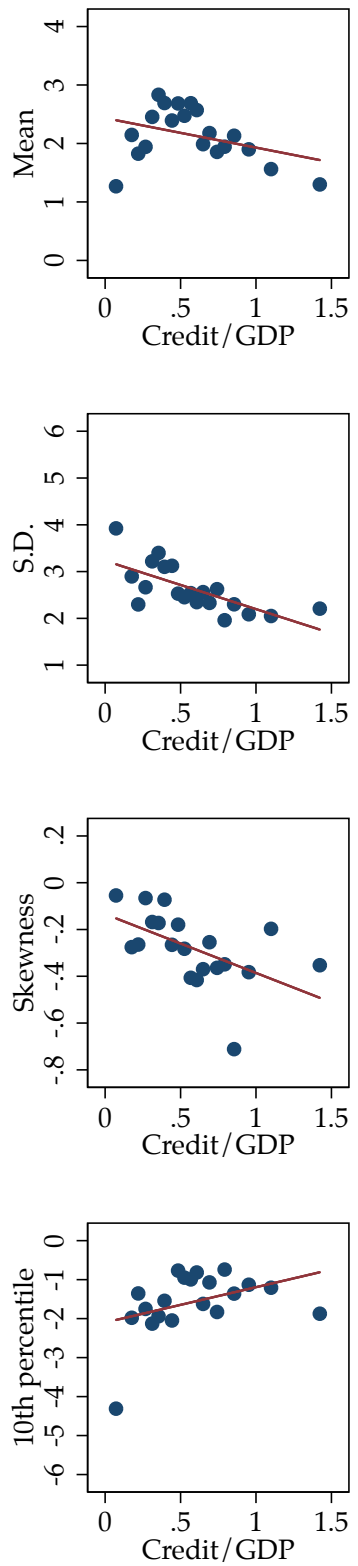

(b) Consumption
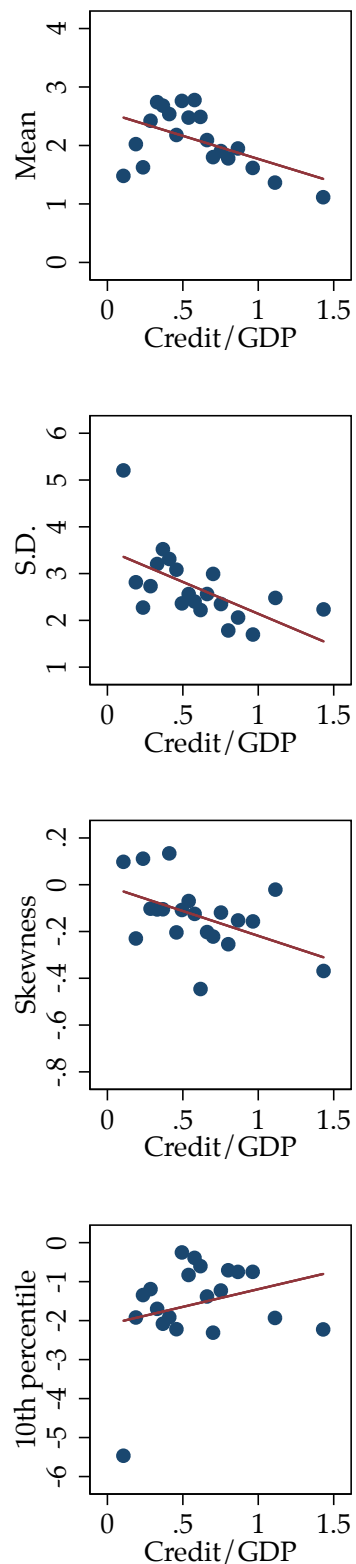

(c) Investment
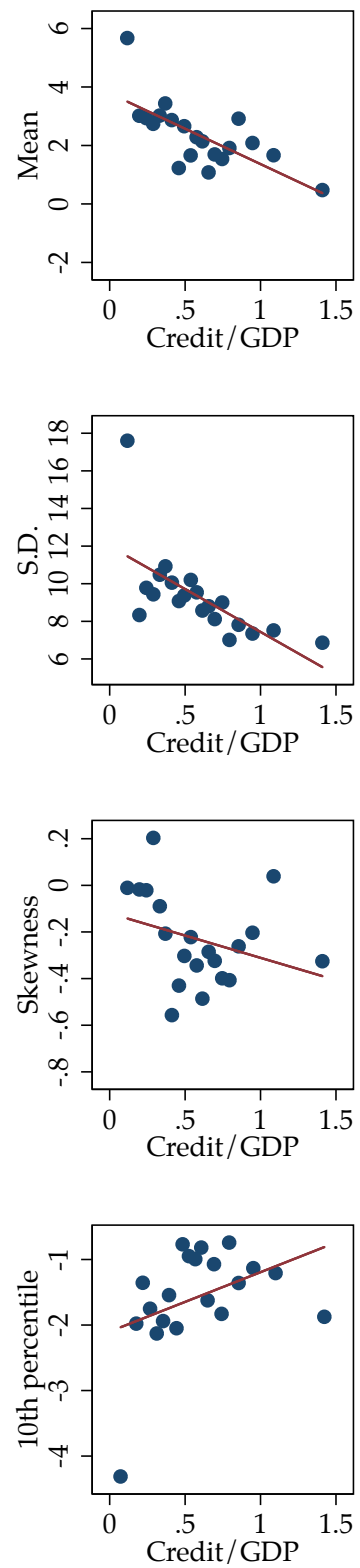

Notes: Binscatters based on 20 bins using 10-year rolling windows to calculate moments. Fitted line obtained using the full sample. See text. 
Figure A.2: Central Moments: binscatters against credit/GDP ratio for mean, s.d., skewness, and 1oth percentile of annual growth rate of real GDP per capita, real consumption per capita, real investment per capita, post-WW2 sample 1950-2013, no fixed effects

(a) GDP
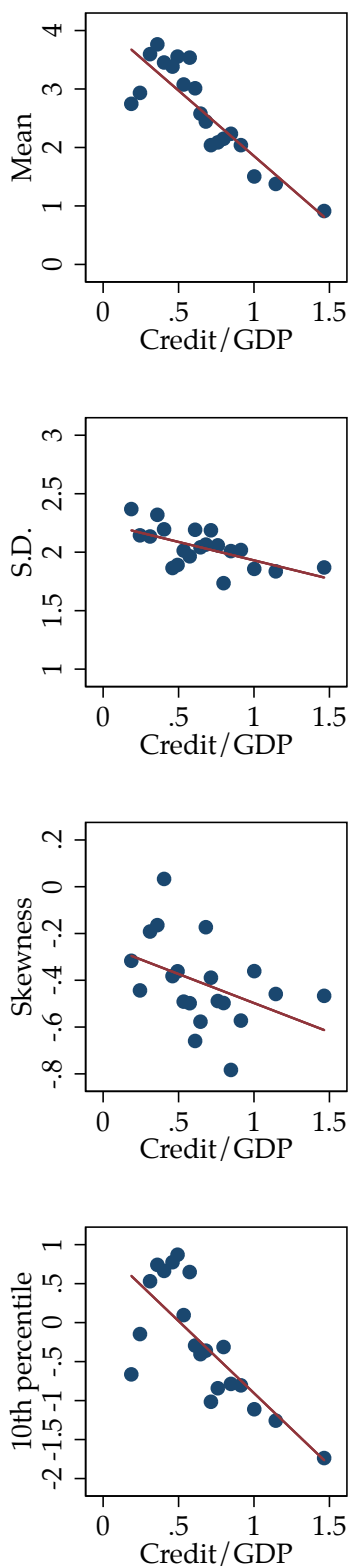

(b) Consumption
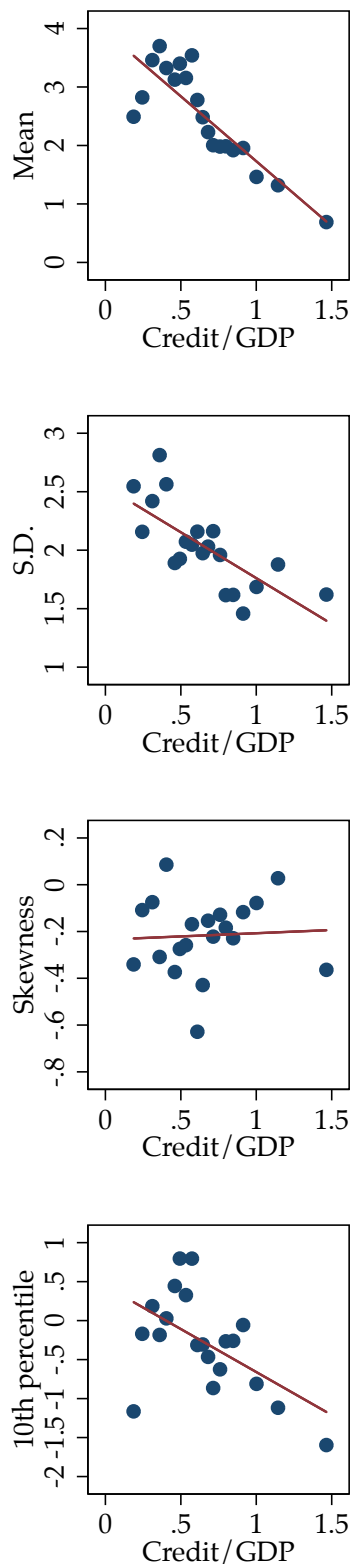

(c) Investment
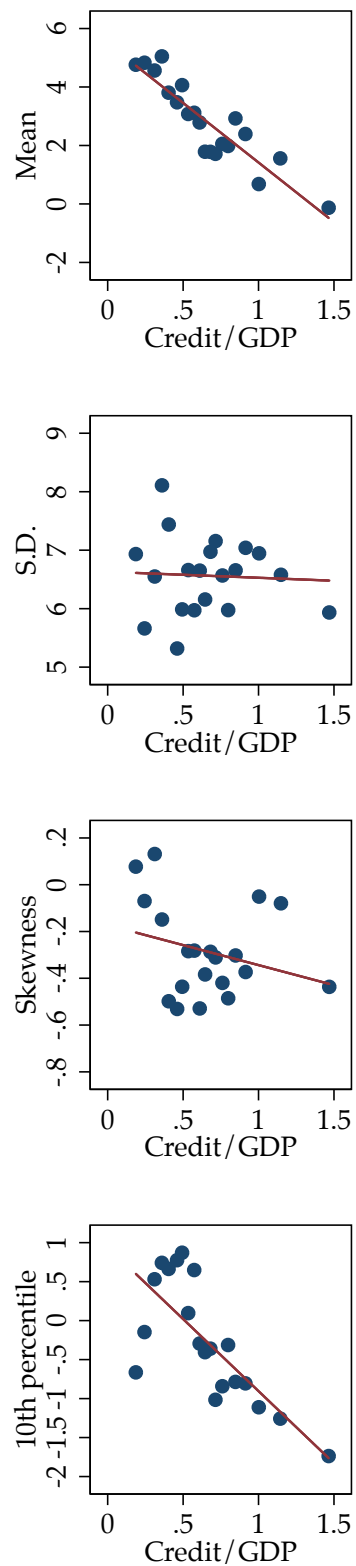

Notes: Binscatters based on 20 bins using 10-year rolling windows to calculate moments. Fitted line obtained using the full sample. See text. 


\section{References}

Acemoglu, Daron, Philippe Aghion, and Giovanni L. Violante. 2001. Deunionization, Technical Change and Inequality. Carnegie-Rochester Conference Series on Public Policy 55(1): 229-264.

Adrian, Tobias, and Nina Boyarchenko. Intermediary Leverage Cycles and Financial Stability. Federal Reserve Bank of New York Staff Report 567.

Ahmed, Shaghil, Andrew Levin, and Beth Anne Wilson. 2004. Recent U.S. Macroeconomic Stability: Good Policies, Good Practices, or Good Luck? Review of Economics and Statistics 86(3): $824-832$.

Arcand, Jean Louis, Enrico Berkes, and Ugo Panizza. 2015. Too much finance? Journal of Economic Growth 20(2): 105-148.

Backus, David K., and Patrick J. Kehoe. 1992. International Evidence on the Historical Properties of Business Cycles. American Economic Review 82(4): 864-888.

Backus, David K., Patrick J. Kehoe, and Finn E. Kydland. 1992. International Real Business Cycles. Journal of Political Economy 100(4): 745-775.

Basu, Susanto, and Alan M. Taylor. 1999. Business Cycles in International Historical Perspective. Journal of Economics Perspectives 13(2): 45-68.

Bernanke, Ben S., Mark Gertler, and Simon Gilchrist. 1999. The Financial Accelerator in a Quantitative Business Cycle Framework. In Handbook of Macroeconomics, vol. 1C, edited by John B. Taylor and Michael Woodford. Amsterdam: Elsevier, pp. 1341-93.

Boivin, Jean, and Marc P. Giannoni. 2006. Has Monetary Policy Become More Effective? Review of Economics and Statistics 88(3): 445-462.

Brunnermeier, Markus K., and Yuliy Sannikov. 2014. A Macroeconomic Model with a Financial Sector. American Economic Review 104(2): 379-421.

Caballero, Ricardo, Emmanuel Farhi, and Pierre-Olivier Gourinchas. 2008. An Equilibrium Model of "Global Imbalances" and Low Interest Rates. American Economic Review 98(1): 358-393.

Canova, Fabio. 1998. Detrending and Business Cycle Facts. Journal of Monetary Economics 41(3): 475-512.

Cecchetti, Stephen G., and Enisse Kharroubi. 2015. Why Does Financial Sector Growth Crowd Out Real Economic Growth? CEPR Discussion Paper 10642.

Demirgüç-Kunt, Asli, Edward Kane, and Luc Laeven. 2013. Deposit Insurance Database. World Bank Policy Research Working Paper 6934. Washington, D.C.: World Bank.

Eggertsson, Gauti B., and Paul Krugman. 2012. Debt, Deleveraging, and the Liquidity Trap: A Fisher-Minsky-Koo Approach. Quarterly Journal of Economics 127(3): 1469-1513.

Foote, Christopher L., Kristopher S. Gerardi, and Paul S. Willen. 2012. Why Did So Many People Make So Many Ex Post Bad Decisions? NBER Working Paper 18082. 
Goldsmith, Raymond W. 1985. Comparative National Balance Sheets: A Study of Twenty Countries, 1688-1979. Chicago: University of Chicago Press.

Harding, Don, and Adrian Pagan. 2002. Dissecting the Cycle: A Methodological Investigation. Journal of Monetary Economics 49(2): 365-381.

Hodrick, Robert J., and Edward C. Prescott. 1997. Postwar U.S. Business Cycles: An Empirical Investigation. Journal of Money, Credit and Banking 29(1): 1-16.

Hoffman, Philip T., Gilles Postel-Vinay, and Jean-Laurent Rosenthal. 20oo. Priceless Markets: The Political Economy of Credit in Paris, 1660-1870. Chicago: University of Chicago Press.

Jordà, Òscar, Moritz Schularick, and Alan M. Taylor. 2011. Financial Crises, Credit Booms, and External Imbalances. IMF Economic Review 59: 340-378.

Jordà, Òscar, Moritz Schularick, and Alan M. Taylor. 2013. When Credit Bites Back. Journal of Money, Credit, and Banking 45(s2): 3-28.

Jordà, Òscar, Moritz Schularick, and Alan M. Taylor. 2015. Betting the House. Journal of International Economics 96(S1): S2-S18.

Jordà, Òscar, Moritz Schularick, and Alan M. Taylor. 2016a. The Great Mortgaging: Housing Finance, Crises, and Business Cycles. Economic Policy 31(85): 107-152.

Jordà, Òscar, Moritz Schularick, and Alan M. Taylor. 2016b. Sovereigns vs. Banks: Credit, Crises and Consequences. Journal of the European Economic Association 14(1): 45-79.

King, Robert G., and Ross Levine. 1993. Finance, Entrepreneurship and Growth. Journal of Monetary Economics 32(3): 513-542.

Knoll, Katharina, Moritz Schularick, and Thomas Steger. 2015. No Price Like Home: Global House Prices. CEPR Discussion Paper 10166.

Kocherlakota, Narayana R. 2000. Creating Business Cycles through Credit Constraints. Federal Reserve Bank of Minneapolis Quarterly Review 24(3): 2-10.

Korinek, Anton, and Alp Simsek. 2016. Liquidity Trap and Excessive Leverage. American Economic Review 106(3): 699-738.

Kydland, Finn E., and Edward C. Prescott. 1990. Business Cycles: Real Facts and Monetary Myth. Federal Reserve Bank of Minneapolis Quarterly Review 14: 3-18.

McConnell, Margaret, and Gabriel Pérez-Quirós. 2000. Output Fluctuations in the United States: What Has Changed since the Early 1980s. American Economic Review 90(5): 1464-1476.

McKay, Alisdair, and Ricardo Reis. 2008. The Brevity and Violence of Contractions and Expansions. Journal of Monetary Economics 55: 738-751.

Mian, Atif, and Amir Sufi. 2013. Household Leverage and the Recession of 2007-09. IMF Economic Review 58(1): 74-117.

Mian, Atif, and Amir Sufi. 2014. House of Debt: How They (and You) Caused the Great Recession, and How We Can Prevent It from Happening Again. Chicago: University of Chicago Press. 
Mitchell, Wesley C. 1913. Business Cycles. Berkeley, Calif.: University of California Press.

Mitchell, Wesley C. 1927. Business Cycles: The Problem and Its Setting. New York: National Bureau of Economic Research.

Monnet, Eric. 2014. Monetary Policy without Interest Rates: Evidence from France's Golden Age (1948 to 1973) using a Narrative Approach. American Economic Journal: Macroeconomics 6(4): 137-69.

Nakov, Anton, and Andrea Pescatori. 2010. Oil and the Great Moderation. Economic Journal 120(543): 131-156.

Philippon, Thomas, and Ariell Reshef. 2013. An International Look at the Growth of Modern Finance. Journal of Economic Perspectives 27(2): 73-96.

Piketty, Thomas, and Gabriel Zucman. 2013. Capital is Back: Wealth-Income Ratios in Rich Countries, 1700-2013. CEPR Discussion Paper 9588.

Reinhart, Carmen, and Kenneth S. Rogoff. 2013. Banking crises: An equal opportunity menace. Journal of Banking and Finance 37(11): 4557-73.

Reinhart, Carmen, and Kenneth S. Rogoff. 2009. This Time is Different: Eight Centuries of Financial Folly. Princeton, N.J.: Princeton University Press.

Schularick, Moritz, and Alan M. Taylor. 2012. Credit Booms Gone Bust: Monetary Policy, Leverage Cycles, and Financial Crises. American Economic Review 102(2): 1029-61.

Stock, James H., and Mark W. Watson. 2005. Understanding Changes in International Business Cycle Dynamics. Journal of the European Economic Association 3(5): 968-1006.

Zarnowitz, Victor. 1992. Facts and Factors in the Recent Evolution of Business Cycles in the United States. In Business Cycles: Theory, History, Indicators, and Forecasting. Cambridge, Mass.: National Bureau of Economic Research, pp. 77-124. 